\title{
Antimicrobial resistance from a one health perspective in Cameroon: a systematic review and meta-analysis
}

\author{
Mohamed Moctar Mouliom Mouiche ${ }^{1,2^{*}+}$ (D), Frédéric Moffo ${ }^{1,3+}$, Jane-Francis Tatah Kihla Akoachere ${ }^{4}$, \\ Ndode Herman Okah-Nnane ${ }^{1,5}$, Nabilah Pemi Mapiefou', Valantine Ngum Ndze ${ }^{6}$, Abel Wade ${ }^{7}$, \\ Félicité Flore Djuikwo-Teukeng ${ }^{8}$, Dorine Godelive Tseuko Toghoua ${ }^{9}$, Henri René Zambou ${ }^{10}$, \\ Jean Marc Kameni Feussom ${ }^{10,11}$, Matthew LeBreton ${ }^{2}$ and Julius Awah-Ndukum 1,3,12
}

\begin{abstract}
Background: Antimicrobial resistance (AMR) is widely acknowledged as a global health problem, yet in many parts of the world its magnitude is not well elucidated. A baseline assessment of the AMR prevalence is a priority for implementation of laboratory-based AMR surveillance This review, focused on a One health approach, aimed at describing the current status of AMR in Cameroon.

Methods: PubMed, Google Scholar and African Journals Online databases were searched for articles published in English and French in accordance with the PRISMA guidelines. Retrieval and screening of article was done using a structured search string with strict inclusion/exclusion criteria. Free-text and grey literature were obtained by contacting the authors directly. The pooled prevalence and 95\% confidence intervals were calculated for each pathogen-antibiotic pairs using random-effects models.
\end{abstract}

Result: Amongst 97 full-text articles reviewed, 66 met the eligibility criteria. The studies originated from the Centre (24; 36.4\%), South-West $(16 ; 24.2 \%)$, West $(13 ; 19.7 \%)$, Littoral $(9 ; 13.6 \%)$ and other $(4 ; 6.1 \%)$ regions of Cameroon. These studies reported AMR in human (45; 68.2\%), animals (9; 13.6\%) and the environment (12; 18.2\%). Overall, 19 species of bacteria were tested against 48 antibiotics. These organisms were resistant to all classes of antibiotics and showed high levels of multidrug resistance. Escherichia coli, Klebsiella pneumoniae and Staphylococcus spp were reported in 23,19 and 18 of the human studies and revealed multidrug resistance (MDR) rates of $47.1 \%$ [95\% Cl (37.3-57.2\%)], 51.0\% [95\% Cl (42.0-59.9)] and 45.2\% [95\% Cl (38.0-54.7)], respectively. Salmonella spp was reported in 6 of the animal studies and showed a MDR rate of $46.2 \%$ [95\% Cl (39.2-53.5\%)] while Staphylococcus spp in 8 of environment studies showed MDR rate of $67.1 \%$ [95\% Cl (55.2-77.2\%)].

(Continued on next page)

\footnotetext{
* Correspondence: mouichemoctar4@gmail.com

${ }^{\dagger}$ Mohamed Moctar Mouliom Mouiche and Frédéric Moffo contributed equally to this work

${ }^{1}$ Department of Pharmacy, Pharmacology and Toxicology, School of

Veterinary Medicine and Sciences, University of Ngaoundéré, Ngaoundéré,

Cameroon

${ }^{2}$ MOSAIC, Yaoundé, Cameroon

Full list of author information is available at the end of the article
}

(c) The Author(s). 2019 Open Access This article is distributed under the terms of the Creative Commons Attribution 4.0 International License (http://creativecommons.org/licenses/by/4.0/), which permits unrestricted use, distribution, and reproduction in any medium, provided you give appropriate credit to the original author(s) and the source, provide a link to the Creative Commons license, and indicate if changes were made. The Creative Commons Public Domain Dedication waiver (http://creativecommons.org/publicdomain/zero/1.0/) applies to the data made available in this article, unless otherwise stated. 


\begin{abstract}
(Continued from previous page)
Conclusion: This review shows that resistance to commonly prescribed antibiotics in Cameroon is high. The findings emphasize the urgent need to address gaps in the standardization of AMR diagnostics, reporting and use of available information to optimize treatment guidelines for the arsenal of antibiotics. Effective AMR surveillance through continued data sharing, large-scale collaboration, and coordination of all stakeholders is essential to understand and manage the AMR national burden.
\end{abstract}

Keywords: Antimicrobial resistance, Bacteria, One health, Human, Animal, Environment, Systematic review, Meta-analysis, Cameroon

\section{Background}

The necessity to improve human health, animal health and agricultural productivity in low- and middle-income countries has led to the extensive use of antimicrobials without respecting therapy guidelines. However, farmers' ignorance of the hazards related to antibiotic therapy and the widespread use of antimicrobials in food-producing animals has escalated the emergence of antimicrobial resistance (AMR) [1]. Thus, the worldwide public health concerns with respect to the antibiotics used in food-producing animals is due to the fact that they are closely related to those used in human medicine and select for resistance. Cross-species transmission of resistant bacteria or resistance genetic elements from animals or environment to humans has been reported $[2,3]$. The World Health Organization (WHO) global report on AMR indicates that resistance of common bacteria has reached alarming levels in many parts of the world with high level resistance of Escherichia coli and Klebsiella spp to third-generation cephalosporin's and carbapenems of up to $54 \%[4,5]$. High resistance rates have been described in bacteria isolated from food-producing animals to major antimicrobials used in human medicine [6-8]. In addition, high resistance rates in bacteria isolated from vegetables and environment have been reported [9].

Largescale and worldwide surveillance is critical to global AMR response. According to a WHO report, Africa has the largest gaps in data on AMR $[5,10]$. A desktop analysis of the implementation of WHO's Policy Package to combat AMR in the WHO African region revealed that two countries -Ethiopia and South-Africa (4.3\%), have national AMR plans in place while $7(14.9 \%)$ other countries have only infection prevention and control policies. Four of these countries are from Eastern Africa (Tanzania, Zimbabwe, Ethiopia, and Kenya), two from southern Africa (Lesotho and South Africa) and one West Africa (Ghana). Furthermore, no African country has a national surveillance system that routinely generates representative, robust data on antimicrobial use and resistance [11].

There is dearth of information on AMR in livestock and agricultural sectors in Africa. Moreover, major gaps exist in the surveillance and sharing of data on AMR emergence among food-borne bacteria and the potential impact on animal and human health [12]. Due to resource constraints, the choice of antibiotic in most parts of Africa including Cameroon is usually not based on knowledge of bacterialsusceptibility. Lack of reliable and quantitative data challenges local and regional treatment guidelines and highlights the need for sustainable efforts by stakeholders towards coordination and harmonization of competences to assess and monitor AMR emergence.

AMR is suspected when there is therapeutic failure evidenced by no convalescence. Limited diagnostic capacity coupled with a high burden of life-threatening bacterial infections has encouraged a pattern of largely empirical antibiotic prescription in human and veterinary medicine in Cameroon. Also, a small repertoire of generic antimicrobials which are often poor quality [13], sold in open markets with little or no regulations, quality control and inappropriate prescription practices [13, 14], are regularly used. Poor personal and environmental hygiene practices have favored the spread of drug resistant pathogens within the hospital environment, causing hospital-acquired infections $[15,16]$. The use of antimicrobials as growth promoters in agriculture has been associated with resistant food borne pathogens and relatively risky to human, animal and environmental health [17]. It is based on this context that this review was done to analyze the available information on AMR emergence in humans, animal and environment as key to effective interventions in Cameroon.

\section{Methods}

\section{Search strategy}

The systematic review was performed in accordance with PRISMA (Preferred Reporting Items for Systematic Reviews and Meta-Analysis) guidelines [18]. PubMed, Google Scholar and African Journals Online databases were used to search articles published in English and French on AMR in Cameroon. Free-text and grey literature were obtained by contacting authors directly. No limit on publication dates was set. Literature search started on March 22, 2018, with an update on December 30, 2018. Reference list of relevant articles were checked 
for additional titles for inclusion in the review. The Boolean search strategy [19] with search terms pertaining to antibiotic resistance, bacteria of interest in relevant study conducted in Cameroon in human and animal health, and the environment was adopted (Fig. 1). These bacteria are important causes of infections in both animal and human and were enrolled in countries' AMR surveillance by the Global Antimicrobial Resistance Surveillance System (GLASS) [20].

\section{Inclusion and exclusion criteria}

Full-text articles on the prevalence of antibiotic resistance among clinical pathogenic bacteria isolated from humans (inpatients and outpatients, healthy volunteers), animals and animal-products (avian, cattle, swine, fish, meat, milk, eggs) and environment (water, hospital surfaces and health care tools, vegetables sold in the market, drainages) in Cameroon were used for the review. Publications were independently reviewed by three authors (FM, MMMM and NPM) to determine eligibility. Disagreements were resolved by consensus or thirdparty consultation (JAN and JFTKA) when consensus could not be achieved. Publications that described human subjects or livestock population studied or type of environmental samples, bacteria isolated, and specific laboratory methods, antimicrobial sensitivity patterns, interpretation of minimum inhibitory concentration breakpoints and diameter of the zone of inhibition of the antibiotics tested were considered and included in the study. As concerns studies related to human, both adult and pediatric patient populations were included. Studies on tuberculosis, non-bacterial pathogens and outbreak disease were not included. Studies reporting aggregated data such as studies with the methodology aggregating resistance rates in a large category such as 'Gram-negative organisms', Gram-positive organisms or 'Enterobacteriaceae' were excluded. As concern animal and environmental studies, articles on prevalence related to aggregate resistance rates and without information on total bacteria isolates were excluded from the review.
Also, articles identified through the literature search that reported AMR in human, animal and environment but that did not report prevalence data were not included in the meta-analysis.

\section{Data extraction}

Data was extracted from individual study using a form and database developed for the purposes of this review using Microsoft Excel 2013. The data extraction was independently done by three co-authors (FM, MMMM and NPM). When there was confrontation of data set, third-party (JAN and JFTKA) consultation was sort for validation. Articles that met the inclusion criteria and reported prevalence data for AMR in bacteria of interest were included in the metaanalysis. Information extracted included article information (first author, year of publication, duration of study and location), and study design (samples size, cross-sectional design or longitudinal study). Specific information on human considered: category of patients (in- or out-patients), type of samples used (pus, blood, throat swabs, stool, nasal swabs, urine, vaginal or wound swabs). In animal: species, number of farms or animals used in analysis, sample type (faeces, meat, milk, blood), sampling point (farm, slaughter house, or retail market) while for the environment, information of interest as water, vegetables, drains, hospital surfaces and medical tools were considered. Antibiotic panels, laboratory procedure, proportion of bacteria investigated and prevalence of antibiotic-resistant bacteria were taken into consideration for the human, animal and environment articles. The following bacteria were included in the search: Escherichia coli, Klebsiella spp, Salmonella spp, Staphylococcus spp, Streptococcus spp, Shigella spp, Proteus spp, Enterococcus spp, Enterobacter spp, Citrobacter spp, Pseudomonas spp, Vibrio spp and Bacillus spp.

\section{Data analysis}

The point estimate prevalence and $95 \%$ confidence interval $(\mathrm{CI})$ of each pathogen-antimicrobial pair in human, animal and environment was pooled using a random effects model. Random-effects meta-analysis was also used

(Antimicrobial resistance* OR antibiotic resistance* OR multiresistant OR multi-drug resistant OR drug resistance OR antibacterial OR antibiotic OR antimicrobial OR bacterial resistance OR enterobacteriaceae OR gram negative OR gram positive) AND (Escherichia coli OR E. coli OR Klebsiella OR Salmonella OR Typhoid OR Enterobacter OR Staphylococcus aureus OR Methicillin-resistant Staphylococcus aureus OR Streptococcus pneumoniae OR Pseudomonas OR Shigella OR Proteus OR Enterococcus OR Cholera OR Vibrio cholerae OR Bacillus OR Citrobacter.) AND (urinary tract OR UTI OR bloodstream infection OR bacteremia OR bactereamia OR sepsis OR Septicemia OR Septiceamia OR diarrhea OR diarrhoea OR acute gastro-intestinal infection OR pneumonia OR acute respiratory infection) AND (human OR Animal OR Environment) AND (Cameroon)*

Fig. 1 Search terms used to identify relevant literature from PubMed, Google Scholar and African Journals Online databases. *These search terms were translated to search articles written in French 
to calculate an overall proportion of pathogen-multidrug resistance pair. If not defined by the study, resistance to two or more antibiotics, frequently used in the primary reports, was considered as multidrug resistance (MDR) [2].

Quality assessment of articles was done using the modified critical appraisal tool developed by Munn et al. [21]. Heterogeneity across the studies was assessed using the Cochrane Q statistics (significant at $p<0.10$ ) and was quantified with the $\mathrm{I}^{2}$ statistic $[19,22]$. Sensitive analysis was performed to evaluate the influence of individual studies on the final effect. The Begg rank correlation [23] and Egger regression asymmetry test [24] were used to examine publication bias. If publication bias was confirmed, a trim-and-fill method developed by Duval and Tweedie [25] was implemented to adjust for the bias. The funnel plot was replicated with their "missing" counterparts around the adjusted summary estimate. If after detailed investigation, there was no obvious cause for the heterogeneity; data was analyzed with a more conservative statistical method that accounted for it. The random-effects meta-analysis attempts to account for the distribution of effects and provided more conservative estimate of the effect $[22,26]$. Subgroup analysis was performed according to the region of the country.

Meta-analysis was done separately for data extracted from the human, animal and environmental articles. $P$ value of 0.05 was considered statistically significant, except in the test of heterogeneity. Data were analyzed using Comprehensive Meta-Analysis Software (Biostat, Inc., New Jersey) Version 3.0 for Windows. In human, point estimates resistance was calculated where if at least four studies reported on the specific bacterium-antibiotic combination, while for animals and environment, it was estimated where three studies reported the same combination (specific bacterium-antibiotic). Overall, MDR prevalence was pooled when five human studies, four animal or environment studies reported combination of specific bacteria resistance to more than two antibiotics.

\section{Results}

The initial search strategy of the online databases in this study identified a total of 509 citations. Additional 58 records were identified by contacting experts in the field of antibiotic use and resistance (12), searching reference lists of included studies (44) and local database (2). A total of 89 duplicates were removed and 478 records were screened for eligibility based on review of title and content of the abstracts. Overall, 381 records were excluded for non-relevance to the research objectives while 97 full-text articles were assessed for eligibility with 66 records meeting the inclusion criteria for the study (Fig. 2). Of these 66 studies included in the review, 52 were rated as good quality (low risk of bias) and 14 were of moderate quality (medium risk of bias). A total of 45 studies reported on the outcome of antibiotic resistance in humans [15, 27-69], 9 reported on the outcome of antibiotic resistance in animals [70-78] and 12 on the environment $[9,15,16,57,62,64,75,79-83]$ (Table 1). Five studies reported outcome of antibiotic resistance in both human and environment while one study reported on the outcome of antibiotic resistance for animals, humans and environment. The largest number of human studies originated from the Centre region (46.7\%) followed by the West (17.8\%), South-West (15.6\%), Littoral (11.1\%) and other (North-West, Adamawa, FarNorth) (4.4\%) regions of the country (Fig. 3). These sources were journal articles (100\%), published in English (88.9\%) with focus on both sex (95.6\%) and 4.4\% strictly on women. These studies investigated Urinary Tract infections (UTIs) (29; 64.4\%), Bloodstream infections (BSIs) (17; 37.8\%), Gastro-intestinal infections (GIIs) (15; 33.3\%), and Respiratory tract infections (RIs) (14; 31.1\%). Overall, 25 types of samples were reported in the various studies, the most abundant being urine samples $(26 ; 57.8 \%)$, followed by vaginal swabs (14; $31.1 \%)$, stool samples $(14 ; 31.1 \%)$, pus $(12 ; 26.7 \%)$, blood (12; $26.7 \%)$, wounds swabs $(10 ; 22.2 \%)$ and others: skin (6; 13.3\%), nasal swabs $(4 ; 8.9 \%)$, Urinary catheter $(4$; $8.9 \%)$, pleural fluid $(4 ; 8.9 \%)$, seminal fluid $(3 ; 6.7 \%)$, bone fragment $(3 ; 6.7 \%)$, septum $(3 ; 6.7 \%)$, sinusitis $(3$; $6.7 \%)$, fingerprinting $(3 ; 6.7 \%)$, throat swabs $(2 ; 4.4 \%)$, eye discharge $(2 ; 4.4 \%)$, ear discharge $(2 ; 4.4 \%)$, urethral smear $(2 ; 4.4 \%)$, corpus and antral biopsy $(1 ; 2.2 \%)$, surgical site $(1 ; 2.2 \%)$, cerebrospinal fluid $(1 ; 2.2 \%)$, ostitis ( $1 ; 2.2 \%)$ and bronchitis $(1 ; 2.2 \%)$.

Nineteen types of pathogens were isolated from samples with the most frequently encountered isolates being Escherichia coli (51.1\%) followed by Klebsiella spp (42.2\%), Staphylococcus spp (40\%), Pseudomonas aeruginosa (24.4\%), Enterobacter spp (17.8\%) and Enterococcus spp (15.6\%). These isolates were tested against 48 antimicrobial agents belonging to 14 families. The studies were conducted in urban settings $(34 / 45 ; 75.5 \%)$, semiurban $(8 / 45 ; 17.8 \%)$ and rural areas $(3 / 45 ; 6.7 \%)$. The majority of patients were hospitalized $(30 / 45 ; 66.7 \%)$ while $19(42.2 \%)$ were outpatient, $10(22.2 \%)$ members of the community, 6 (13.3\%) medical staff and $2(4.4 \%)$ non-medical staff. These were cross sectional prospective studies (93.30\%) and longitudinal studies (6.7\%). With regards to the type of microbiology laboratory used, the studies were carried out in teaching hospitals partnering with an associated laboratory $(22 / 45 ; 48.9 \%)$, routine clinical laboratories $(19 / 45 ; 42.2 \%)$ as well as research laboratories $(4 / 45 ; 8.9 \%)$. The disk diffusion test $(37 / 45 ; 82.2 \%)$ was predominantly used for antibiotic susceptibility testing followed by dilution test (4/45; 


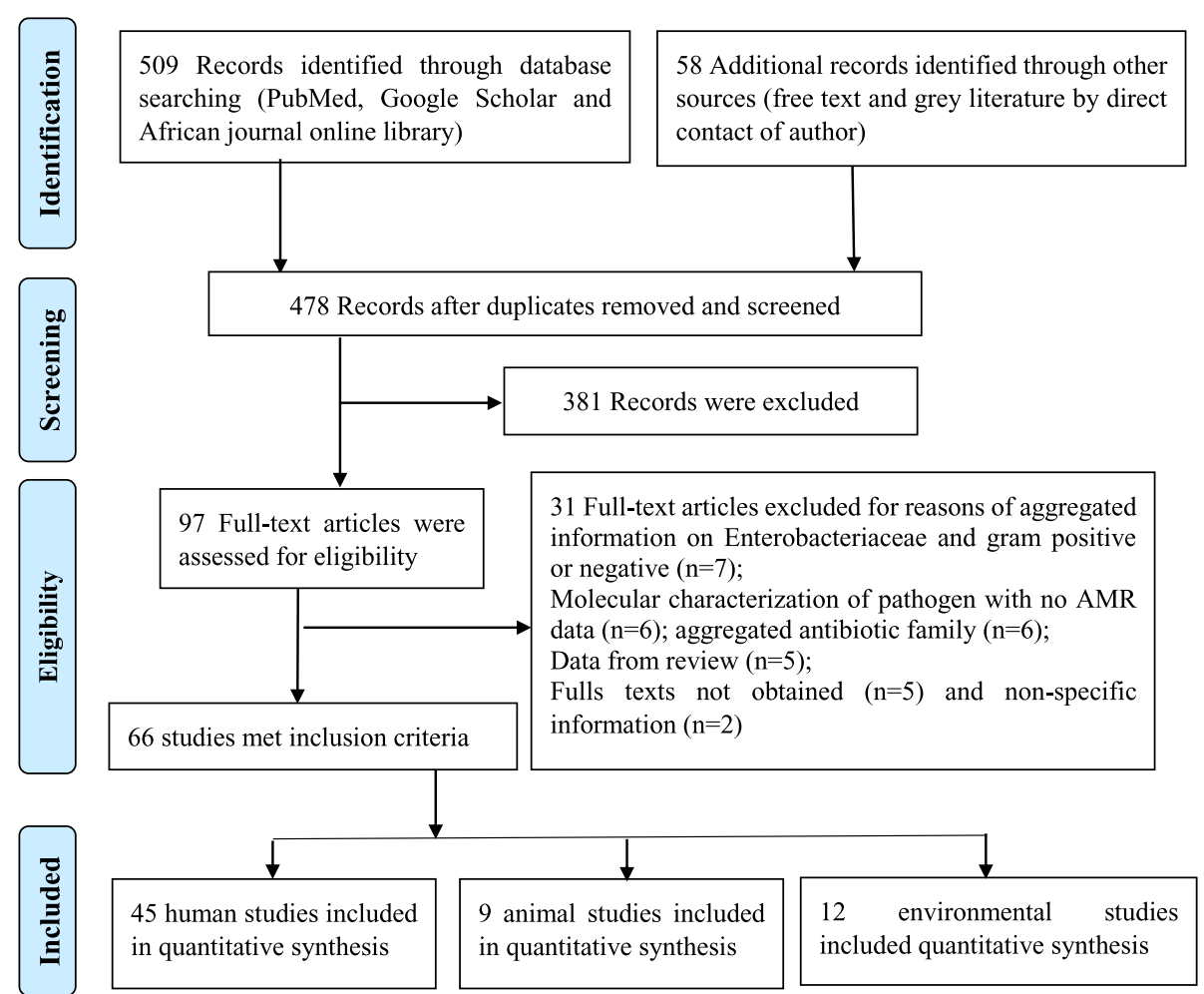

Fig. 2 Prisma Flow-chart illustrating the study selection process on antimicrobial resistance in Cameroon

$8.9 \%)$ and Etest $(2 / 45 ; 4.4 \%)$. Some studies used both diffusion and dilution test $(2 / 45 ; 4.4 \%)$ and diffusion and Etest $(1 / 45 ; 2.2 \%)$. The following microbiological standards were used as references: the Clinical Laboratory Standard Institute $(20 / 45,44.4 \%)$, the French Society of Microbiology $(16 / 45 ; 35.6 \%)$, European Committee on Antimicrobial Susceptibility Testing $(1 / 45 ; 2.2 \%)$, American Type Culture Collection $(1 / 45 ; 2.2 \%)$, and both French Society of Microbiology and European Committee on Antimicrobial Susceptibility Testing (3/45; 6.7\%). Four $(8.9 \%)$ studies did not clearly define the susceptibility laboratory references used.

Animal studies originated from four regions: SouthWest (33.3\%), Adamawa (22.2\%), Centre (22.2\%), and West (22.2\%) while environmental studies were from South-West (41.7\%), Littoral (33.3\%) and West (25\%) regions (Fig. 3). Seven animal's studies were journal articles published in English and two Doctor of Veterinary Medicine dissertations written in French. A total of 12 environmental studies were journal articles published in English. Animal and environmental studies were crosssectional designs. Poultry $(5 / 9 ; 55.6 \%)$ was the most studied animal population, followed by beef cattle (2/9; $22.2 \%)$. Faecal/cloacal swabs/caecum $(7 / 9 ; 77.8 \%)$ were the most harvested samples in animal studies while in environmental studies, swabs of hospital surfaces and medical devices $(50 \%)$ and water samples $(25 \%)$ were the most investigated. Results reported Salmonella spp (66.6\%) and Escherichia coli (33.3\%) as the most isolated organisms in animal studies and Staphylococcus spp (66.7\%), Bacillus spp (50\%) and Pseudomonas aeruginosa (33.3\%) in environmental studies. For the animal studies, 7 articles made use of disk diffusion tests while 2 used both diffusion and dilution tests. The Clinical Laboratory Standard Institute standards were used as reference in 5(55.6\%) studies while the rest used the French Society of Microbiology standards (4/9; 44.4\%). All environmental studies made use of disk diffusion tests, but microbiological reference standards of the Clinical Laboratory Standard Institute were used by $63.6 \%)(7 / 11)$ and the French Society of Microbiology by $36.4 \%$ (4/11).

\section{Antibiotic resistance rates in human studies}

Of the 45 studies reporting antibiotic resistance in human, 34 were included in the meta-analysis. Bacterial resistance rates were carried out without distinguishing between patient and healthy volunteers (Table 2). Generally, a higher level of resistance of E. coli, Klebsiella spp, Staphylococcus spp, Pseudomonas aeruginosa, Enterobacter spp, and Proteus spp to all classes of antibiotics was observed. Lower levels of E. coli resistance were observed for Gentamicin 36.5\% [95\% CI (23.7-51.5\%)], Ceftriaxone 38.7\% [95\% CI (25.7-53.6\%)] and Ciprofloxacin 39.1\% [95\% CI (28.151.2\%)] compared with resistance to Tetracycline $71.9 \%$ 
Table 1 Distribution and characteristics of studies used in the review

\begin{tabular}{|c|c|c|c|}
\hline & Number of human studies $(n=45)$ & Number of animal studies $(n=9)$ & Number of environmental studies $(n=12)$ \\
\hline \multicolumn{4}{|l|}{ Region } \\
\hline Adamawa & $1(2.2 \%)$ & $2(22.2 \%)$ & \\
\hline Centre & $21(46.7 \%)$ & $2(22.2 \%)$ & \\
\hline Far-north & $1(2.2 \%)$ & & \\
\hline Littoral & $5(11.1 \%)$ & & $4(33.3 \%)$ \\
\hline North-west & $2(4.4 \%)$ & & \\
\hline South-west & $7(15.6 \%)$ & $3(33.3 \%)$ & $5(41.7 \%)$ \\
\hline West & $8(17.7 \%)$ & $2(22.2 \%)$ & $3(25 \%)$ \\
\hline \multicolumn{4}{|l|}{ Type of material } \\
\hline Journal article & $45(100 \%)$ & $7(77.8 \%)$ & $12(100 \%)$ \\
\hline Dissertation (Unpublished) & & $2(22.2 \%)$ & \\
\hline \multicolumn{4}{|l|}{ Language } \\
\hline English & $40(88.9 \%)$ & $5(55.6 \%)$ & $12(100 \%)$ \\
\hline French & $5(11.1 \%)$ & $4(44.4 \%)$ & \\
\hline \multicolumn{4}{|l|}{ Study design } \\
\hline Cross sectional & $42(93.3 \%)$ & $9(100 \%)$ & $12(100 \%)$ \\
\hline Longitudinal & $2(6.7 \%)$ & & \\
\hline \multicolumn{4}{|c|}{ Animal and human population study } \\
\hline Beef cattle & & $2(22.2 \%)$ & \\
\hline Poultry: broilers \& eggs layers & & $5(55.6 \%)$ & \\
\hline Swine & & $1(11.1 \%)$ & \\
\hline Shrimps & & $1(11.1 \%)$ & \\
\hline Healthy adults & $5(11.1 \%)$ & & \\
\hline Patients or cases & $36(80 \%)$ & & \\
\hline Health care personnel & $4(8.9 \%)$ & & \\
\hline \multicolumn{4}{|l|}{ Common infection } \\
\hline Urinary tract infection & $29(64.4 \%)$ & & \\
\hline Bloodstream infection & $17(37.8 \%)$ & & \\
\hline Gastro-intestinal infection & $15(33.3 \%)$ & & \\
\hline Respiratory infection & $14(31.1 \%)$ & & \\
\hline Skin problems & $6(13.3 \%)$ & & \\
\hline Eye and ear discharge & $5(11.1 \%)$ & & \\
\hline \multicolumn{4}{|l|}{ Samples studied } \\
\hline Faecal/cloacal swabs/caecum & & $7(77.8 \%)$ & \\
\hline Meat or carcass & & $1(11.1 \%)$ & \\
\hline Shrimps & & $1(11.1 \%)$ & \\
\hline Stool sample & $14(31.1 \%)$ & & \\
\hline Urine & $26(57.8 \%)$ & & \\
\hline Vaginal swabs & $14(31.1 \%)$ & & \\
\hline Blood & $12(26.7 \%)$ & & \\
\hline Pus & $12(22.7 \%)$ & & \\
\hline Wounds swabs & $10(22.2 \%)$ & & \\
\hline Skin & $6(13.3 \%)$ & & \\
\hline Nasal swabs & $4(8.9 \%)$ & & \\
\hline
\end{tabular}


Table 1 Distribution and characteristics of studies used in the review (Continued)

\begin{tabular}{|c|c|c|c|}
\hline & Number of human studies $(n=45)$ & Number of animal studies $(n=9)$ & Number of environmental studies $(n=12)$ \\
\hline Medical tools and devices & & & $6(50 \%)$ \\
\hline Water & & & $3(25 \%)$ \\
\hline uncooked vegetables & & & $1(8.3 \%)$ \\
\hline Money (notes and coins) & & & $1(8.3 \%)$ \\
\hline Abattoirs drains & & & $1(8.3 \%)$ \\
\hline \multicolumn{4}{|l|}{ Bacteria isolates studied } \\
\hline Escherichia coli & $23(51.1 \%)$ & $3(33.3 \%)$ & $3(25 \%)$ \\
\hline Salmonella spp. & $1(2.1 \%)$ & $6(66.7 \%)$ & $1(8.3 \%)$ \\
\hline Klebsiella spp & $19(42.2 \%)$ & & $3(25 \%)$ \\
\hline Enterococcus spp & $7(15.6 \%)$ & $1(11.1 \%)$ & $2(16.7 \%)$ \\
\hline Proteus spp & $6(13.3 \%)$ & $2(22.2 \%)$ & $2(16.7 \%)$ \\
\hline Citrobacter spp & $4(8.9 \%)$ & & \\
\hline Staphylococcus spp. & $18(40 \%)$ & $1(11.1 \%)$ & $8(66.7 \%)$ \\
\hline Streptococcus spp & $6(13.3 \%)$ & & $1(8.3 \%)$ \\
\hline Pseudomonas aeruginosa & $11(24.4 \%)$ & & $4(33.3 \%)$ \\
\hline Bacillus spp & $2(4.4 \%)$ & & $6(50 \%)$ \\
\hline Shigella spp & $2(4.4 \%)$ & & $3(25 \%)$ \\
\hline Vibrio cholerae & $1(2.1 \%)$ & $1(11.1 \%)$ & $3(25 \%)$ \\
\hline
\end{tabular}

[(95\% CI (66.1-88.0\%)], Amoxicillin 77.3\% [95\% CI (59.788.7\%)] and Trimethoprim / Sulfamethoxazole 85.2\% [95\% CI (69.1-93.7\%)]. Overall, an E. coli multidrug resistance rate of $47.1 \%$ [95\% CI (37.3-57.2\%); $\mathrm{I}^{2}=84.82 \%$; $p<$ 0.001)] was observed (Fig. 4).

With regards to Klebsiella spp, low resistance to Ciprofloxacin 26.7\% [95\% CI (15.7-42.0\%)] and Gentamicin $30.6 \%$ [95\% CI (20.2-63.0\%)] was observed compared with Trimethoprim/Sulfamethoxazole $78.3 \% \quad[95 \%$ CI (69.6-85.1\%)] and Amoxicillin 94.7\% [95\% CI (84.998.3\%)]. Overall, the prevalence of multidrug resistance in Klebsiella spp was $51.3 \%$ [95\% CI (42.5-60.0); $\mathrm{I}^{2}$ : 59.07\%; $p<0.01$ ] (Fig. 5).

Among Staphylococcus spp isolates, the lowest pooled resistance rates were in Nitrofurantoine 34.1\% [95\% CI (22.3-48.2\%)] and Ciprofloxacin 42.9\% [95\% CI (20.6$68.6 \%)$ ] compared with other commonly used agents such as Beta-lactams with high level of AMR (Table 2).

With regards to Beta-lactams, pooled AMR ranged from $52.9 \%$ [95\% CI (23.4-80.5\%)], to 91.1\% [95\% CI (77.4-96.9\%)] for Ceftazidime and Cefotaxime, respectively. High resistance rates were also observed in Trimethoprim/Sulfamethoxazole 81.5\% [95\% CI (52.594.6\%) and Penicillin 95.8\% [95\% CI (85.2-98.9\%)]. Multidrug resistance rate of $45.2 \%$ [95\% CI (38.0$\left.\left.54.7 \% ; \quad \mathrm{I}^{2}=80.61 \% ; \quad p<0.0001\right)\right] \quad$ was recorded in Staphylococcus spp (Fig. 6).

As concerned Pseudomonas aeruginosa, Enterobacter spp, and Proteus spp, the lowest pooled resistance rate was $24.8 \%$ [95\% CI (15.8-37.0\%)] to Ceftazidime and
$30.6 \%$ [95\% CI $(20.2-63.0 \%)]$ to Gentamicin. MDR prevalence rates of $51.9 \%$ [95\% CI (41.9-61.8\%), $\mathrm{I}^{2}=$ $1.18 \%, p=0.415$ ] and $56.8 \%$ [95\% CI (40.5-71.7\%), $\mathrm{I}^{2}=$ $56.011 \%, p=0.0045]$ were observed for Enterobacter spp and Proteus spp, respectively (Fig. 7).

Based on the region where the studies were reported (Table 3), the pooled estimate of MDR was moderate to high of E. coli, Staphylococcus spp and Klebsiella spp regularly isolated in hospital settings. However, there was no significant difference $(p>0.05)$ in multidrug resistance of respective pathogens across regions.

\section{Antibiotic resistance rates in animals}

Out of 9 studies reporting antibiotic resistance in animals, 7 were included in meta-analysis. Resistance rates were pooled if at least three studies reported on a specific bacterium-antibiotic combination (Table 4). Generally, high levels of resistance of E. coli and Salmonella spp to all classes of antibiotics tested was observed. The pooled resistance rate of E. coli was lower with Gentamicin: $25.4 \%$ [(95\% CI 10.1.091.7\%)] compared to Trimethoprim/Sulfamethoxazole: 83.3\% [(95\% CI (51.3-96.0\%)].

With regards to Salmonella spp from animal studies, Amoxicillin/Clavulanic acid was more susceptible compared to Tetracycline. Overall, MDR recorded for $E$. coli was 76.2\% [95\% CI (53.0-90.1\%), $\mathrm{I}^{2}=79.68 \% p=0.002$ ] and for Salmonella spp 45.3\% [95\% CI (38.3-52.5\%), $\mathrm{I}^{2}=80.61 \% ; p<0.0001$ ] (Fig. 8). 


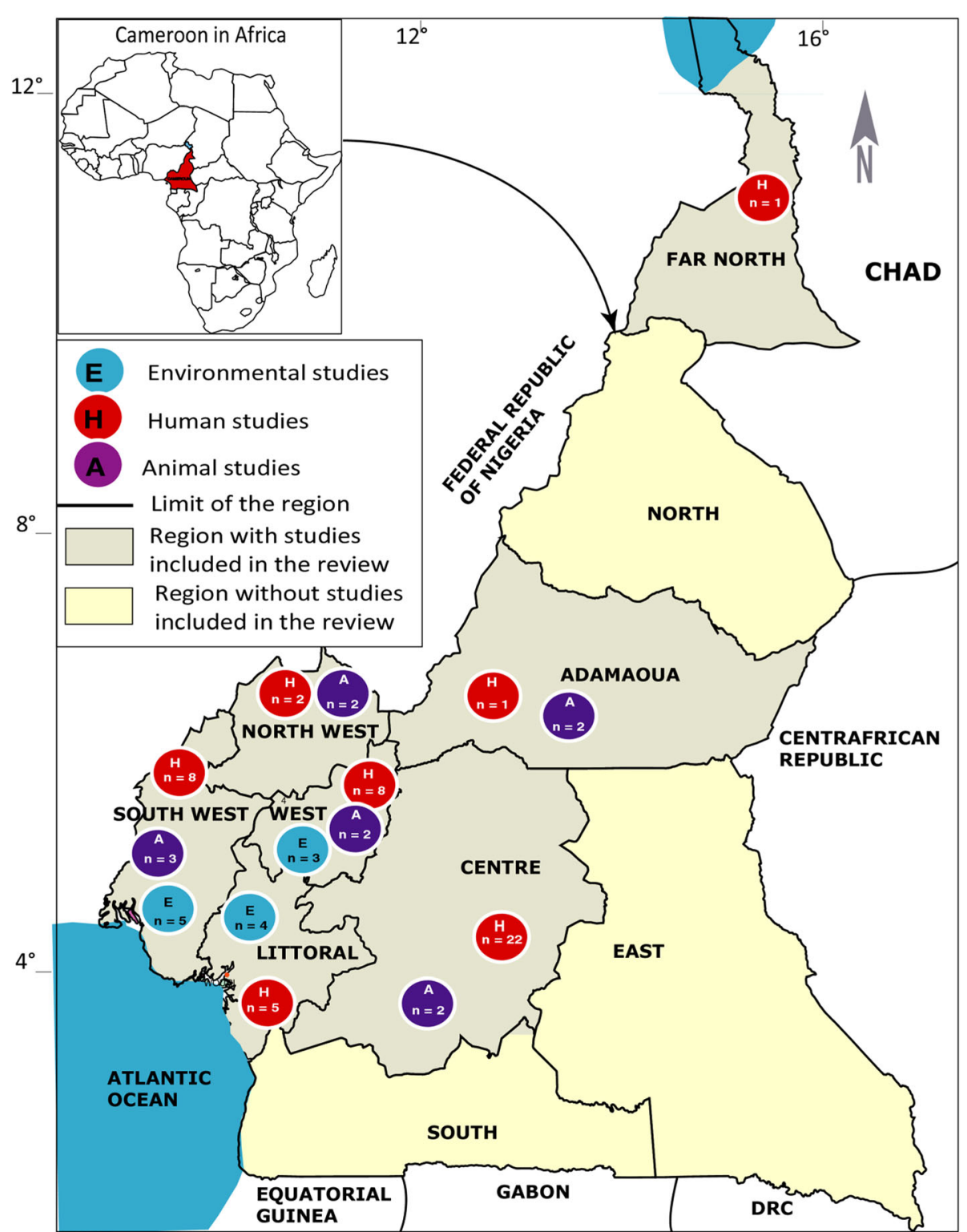

Fig. 3 Map of the Cameroon showing study sites and the number of articles used in the review

\section{Antibiotic resistance rates in the environment}

Out of 12 studies reporting antibiotic resistance in the environment, 9 were included in meta-analysis. Resistance rates were pooled if at least three studies reported on a specific bacterium-antibiotic combination (Table 5). Generally, a higher level of resistance of Vibrio cholerae, Bacillus spp and Staphylococcus spp to all classes of antibiotics tested was observed.

Vibrio cholerae recorded a lower rate of resistance to Chloramphenicol: $19.1 \%$ [(95\% CI (2.4-69.0\%)] compared to $53.6 \%$ [(95\% CI (47.3-59.8\%)] with Ampicillin. Pooled estimate of antimicrobial resistance prevalence of Bacillus spp was lower for Gentamicin: 14.0\% [(95\% CI (6.6-27.1\%)] and Ciprofloxacin: 28.1\% [(95\% CI (23.9-
$32.8 \%)]$ compared to the third-generation cephalosporin Cefoxitine: $88.7 \%$ [(95\% CI (74.5-95.5\%)].

Amongst isolated Staphylococcus spp, pooled estimate of prevalence rate was high in all molecule regularly used in hospital settings. Multidrug resistance (Fig. 9) of Bacillus spp, Vibrio cholerae and Staphylococcus spp of $50.3 \%$ [(95\% CI (24.3-76.1\%); $\left.\mathrm{I}^{2}=52.75 \% ; p=0.096\right]$, $53.3 \%$ [(95\% CI $\left.(27.0-77.9 \%) \mathrm{I}^{2}=97.15 \%, p<0.0001\right]$ and $67.1 \%$ [(95\% CI $\left.\left.(55.2-77.2 \%) \mathrm{I}^{2}=92.85 \%, p=0.0001\right)\right]$ respectively, were recorded.

\section{Discussion}

Antimicrobial resistance is a complex issue of global health concern. AMR is on the increase and threatens 
Table 2 Pooled prevalence rates of antibiotic resistance of bacteria based on a meta-analysis of human studies

\begin{tabular}{|c|c|c|c|}
\hline Bacteria reported in the studies reviewed & Antimicrobial agent & Number of studies & Pooled prevalence of AMR (95\% Cl) \\
\hline \multirow[t]{20}{*}{ Escherichia coli } & Beta-lactams & & \\
\hline & Amoxicillin & 10 & $77.3(59.7-88.7)$ \\
\hline & Amoxicillin+ Clavulanic acid & 8 & $63.3(48.9-75.9)$ \\
\hline & Ampicillin & 4 & $65.6(37.9-85.6)$ \\
\hline & Ceftriaxone & 7 & $38.7(25.7-53.6)$ \\
\hline & Aminoglycosides & & \\
\hline & Gentamicin & 12 & $36.5(23.7-51.5)$ \\
\hline & Quinolones & & \\
\hline & Nalidixic Acid & 7 & $53.5(35.1-71.0)$ \\
\hline & Ciprofloxacin & 11 & $39.1(28.1-51.2)$ \\
\hline & Tetracyclines & & \\
\hline & Doxycycline & 4 & $45.0(37.0-53.4)$ \\
\hline & Tetracycline & 5 & $71.9(66.1-88.0)$ \\
\hline & Nitrofuranes & & \\
\hline & Nitrofurantoin & 5 & $79.7(66.1-88.0)$ \\
\hline & Phenicols & & \\
\hline & Chloramphenicol & 4 & $50.2(27.0-73.3)$ \\
\hline & Sulfonamides \& Trimethoprim & & \\
\hline & Trimethoprim/Sulfamethoxazole & 6 & $85.2(69.1-93.7)$ \\
\hline & Co-trimoxazole & 4 & $48.8(38.4-59.3)$ \\
\hline \multirow[t]{13}{*}{ Klebsiella spp } & Beta-lactams & & \\
\hline & Amoxicillin & 6 & $94.7(84,9-98.3)$ \\
\hline & Ampicillin & 4 & $76.1(52.5-90.1)$ \\
\hline & Ceftriaxone & 5 & $46.0(32.3-60.4)$ \\
\hline & Aminoglycosides & & \\
\hline & Gentamicin & 9 & $44.1(23.5-67.0)$ \\
\hline & Quinolones & & \\
\hline & Ciprofloxacin & 8 & $26.7(15.7-42.0)$ \\
\hline & Phenicols & & \\
\hline & Chloramphenicol & 6 & $60.0(30.3-83.8)$ \\
\hline & Sulfonamides \& Trimethoprim & & \\
\hline & Trimethoprim/Sulfamethoxazole & 4 & $78.3(69.6-85.1)$ \\
\hline & Co-trimoxazole & 5 & $76.8(47.5-92.7)$ \\
\hline \multirow[t]{11}{*}{ Staphylococcus spp } & Beta-lactams & & \\
\hline & Amoxicillin & 5 & $65.2(51.8-76.5)$ \\
\hline & Amoxicillin+Clavulanic acid & 9 & $50.8(36.4-65.1)$ \\
\hline & Penicillin & 9 & $95.8(85.2-98.9)$ \\
\hline & Ampicillin & 5 & $60.9(27.6-86.5)$ \\
\hline & Oxacillin & 5 & $92.0(46.1-99.4)$ \\
\hline & Ceftriaxone & 8 & $56.7(23.7-88.7)$ \\
\hline & Ceftazidime & 6 & $52.9(23.4-80.5)$ \\
\hline & Cefotaxime & 5 & $91.1(77.4-96.9)$ \\
\hline & Aminoglycosides & & \\
\hline & Gentamicin & 15 & $43.3(23.7-65.3)$ \\
\hline
\end{tabular}


Table 2 Pooled prevalence rates of antibiotic resistance of bacteria based on a meta-analysis of human studies (Continued)

\begin{tabular}{|c|c|c|c|}
\hline Bacteria reported in the studies reviewed & Antimicrobial agent & Number of studies & Pooled prevalence of AMR ( $95 \%$ Cl) \\
\hline & \multicolumn{3}{|l|}{ Macrolides } \\
\hline & Erythromycin & 11 & $55.7(47.7-63.4)$ \\
\hline & \multicolumn{3}{|l|}{ Quinolones } \\
\hline & Ciprofloxacin & 9 & $42.9(20.6-68.6)$ \\
\hline & \multicolumn{3}{|l|}{ Sulfonamides \& Trimethoprim } \\
\hline & Trimethoprim/Sulfamethoxazole & 5 & $81.5(52.5-94.6)$ \\
\hline & Co-trimoxazole & 8 & $73.0(47.5-89.0)$ \\
\hline & \multicolumn{3}{|l|}{ Tetracyclines } \\
\hline & Doxycycline & 6 & $53.5(34.2-71.8)$ \\
\hline & Tetracycline & 5 & $68.0(59.3-75.5)$ \\
\hline & \multicolumn{3}{|l|}{ Nitrofuranes } \\
\hline & Nitrofurantoin & 6 & $34.1(22.3-48.2)$ \\
\hline \multirow[t]{7}{*}{ Pseudomonas aeruginosa } & \multicolumn{3}{|l|}{ Monobactams } \\
\hline & Aztreonam & 5 & $59.0(28.9-83.6)$ \\
\hline & \multicolumn{3}{|l|}{ Beta-lactams } \\
\hline & Ceftazidime & 6 & $24.8(15.8-37.0)$ \\
\hline & Cefotaxime & 4 & $78.6(60.6-89.8)$ \\
\hline & \multicolumn{3}{|l|}{ Aminoglycosides } \\
\hline & Gentamicin & 6 & $46.9(38.2-55.8)$ \\
\hline \multirow[t]{6}{*}{ Enterobacter spp } & \multicolumn{3}{|l|}{ Aminoglycosides } \\
\hline & Gentamicin & 5 & $30.6(20.2-63.0)$ \\
\hline & \multicolumn{3}{|l|}{ Quinolones } \\
\hline & Ciprofloxacin & 4 & $56.3(36.6-61.7)$ \\
\hline & \multicolumn{3}{|l|}{ Sulfonamides \& Trimethoprim } \\
\hline & Co-trimoxazole & 4 & $83.2(61.2-93.9)$ \\
\hline \multirow[t]{5}{*}{ Proteus spp } & \multicolumn{3}{|l|}{ Beta-lactams } \\
\hline & Amoxicillin & 4 & $61.1(40.2-78.5)$ \\
\hline & Amoxicillin+ Clavulanic acid & 4 & $49.8(23.1-76.6)$ \\
\hline & \multicolumn{3}{|l|}{ Aminoglycosides } \\
\hline & Gentamicin & 4 & $34.7(26.3-44.2)$ \\
\hline
\end{tabular}

the effective management of most bacterial diseases worldwide [5, 84]. However, decreased death and morbidity rates associated with the use of antibiotics based on empirical guidelines are threatened by the development of AMR. Routine susceptibility checks of pathogens as essential keys geared towards strategies against the global AMR crisis have been previously described [10]. The One Health approach based on linking human health and nutrition with animal and environmental health is an improved multi-disciplinary action across these sectors against AMR. The current report reviewed 66 published data of resistance to commonly used antimicrobials in Cameroon. Overall, the review revealed that the level of resistance of bacteria isolated in hospital settings, animal and environment is high for typical empirical antibiotic treatment strategies. Common Enterobacteriaceae pathogens isolated in hospital settings such as E. coli, Klebsiella spp., Enterobacter spp and Proteus spp showed high rates of AMR to ampicillin, amoxicillin, trimethoprim/Sulfamethoxazole, amoxicillin/ clavulanic acid, tetracycline, co-trimoxazole and nalidixic acid. The finding agrees with data obtained in Tanzania (resistance to co-trimoxazole $(77.7 \%)$ and ampicillin (81.6\%) [85] and East Africa (50-100\% resistance to ampicillin and cotrimoxazole) [4].

This review highlights serious concerns relating to the use of ampicillin, amoxicillin and tetracycline as the antibiotics of choice for optimal therapy of common pathogens in Cameroon. Vital information on the burden of antibiotic resistance and concerns on diagnostic capacity and second-line treatment options in the country are also presented. The misuse of antibiotics such as inappropriate prescription of antibiotics, excessive use and 


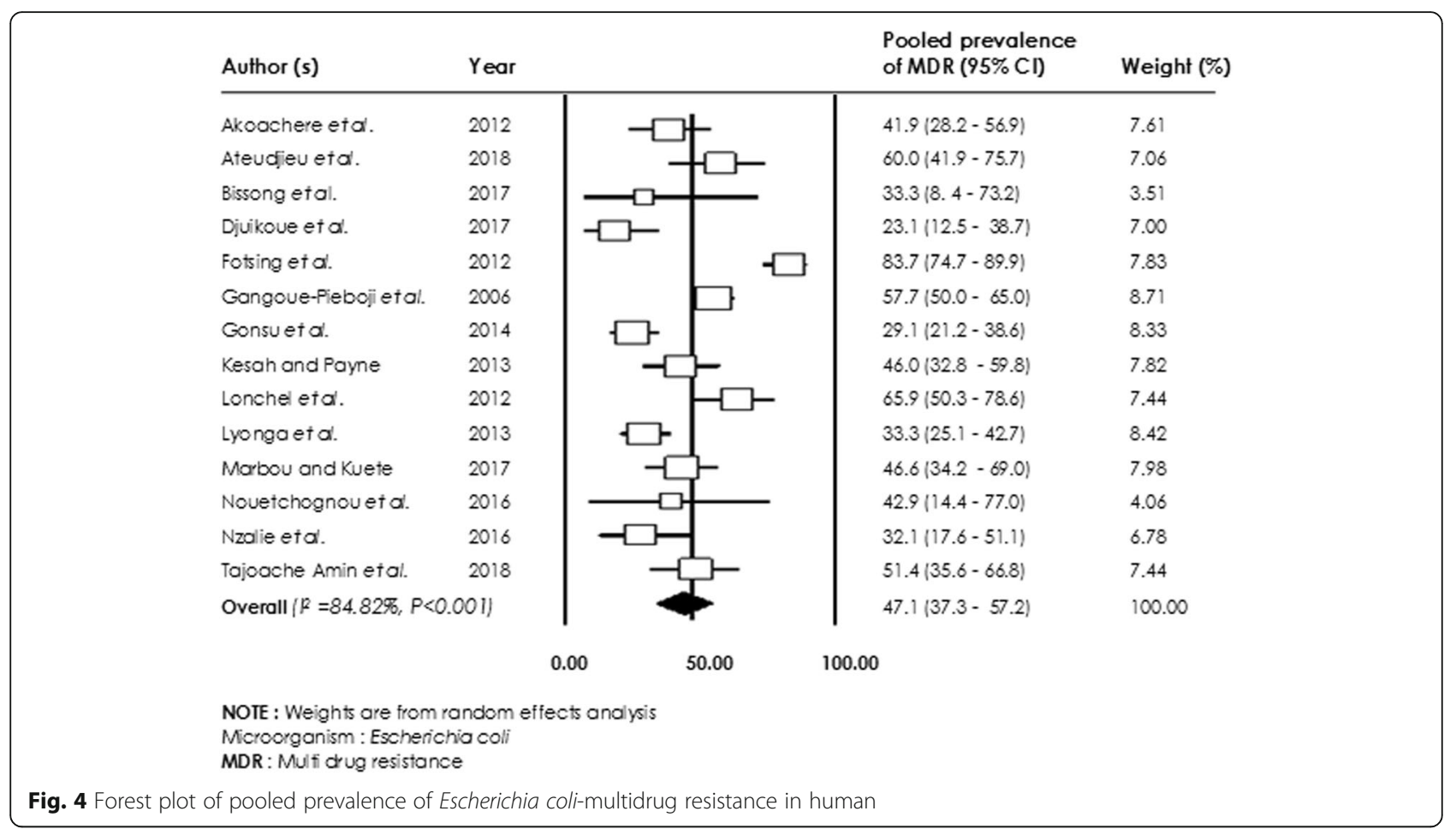

auto-medication and insufficient hygienic practices in health care settings have been reported to contribute to rising levels of AMR [86, 87]. The moderate resistance level (42\%) observed for Staphylococcus spp isolated from hospital settings to third generation cephalosporins, gentamicin and fluoroquinolones was due to the fact that these drugs were usually the last choice of medicine used. This suggests that the choice of antibiotic should be guided by a profile of antimicrobial susceptibility testing results of patients in Cameroon. Multidrug resistance (more than 10 antibiotics) of common bacteria such as E. coli (47.1\%), Klebsiella spp (51.0\%) and Staphylococcus spp (45.2\%) were further evidence of high and widespread AMR in Cameroon. The review revealed that AMR is a growing health problem and major concerns among hospitalized persons and risk communities. Generally, antibiotic

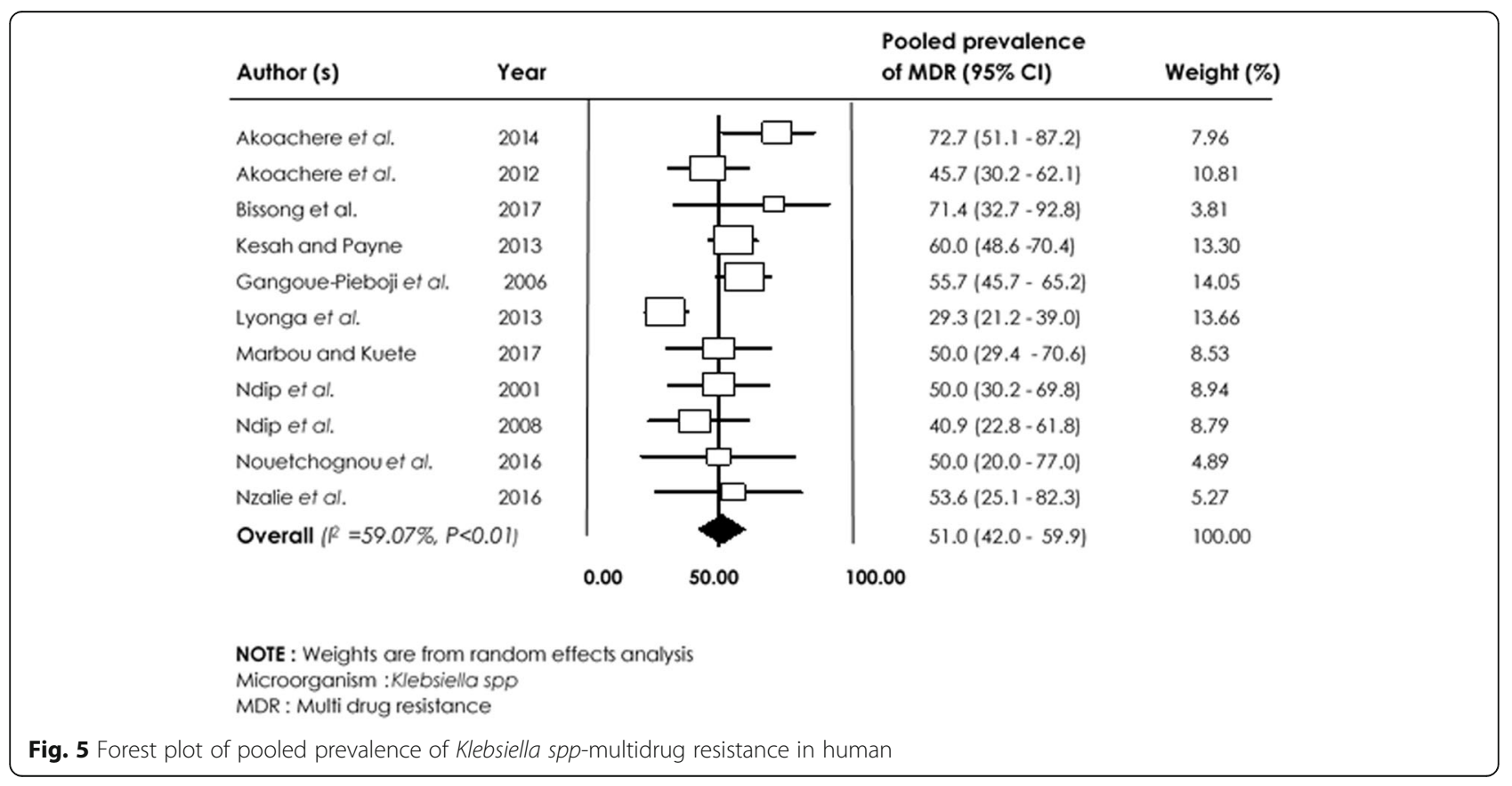




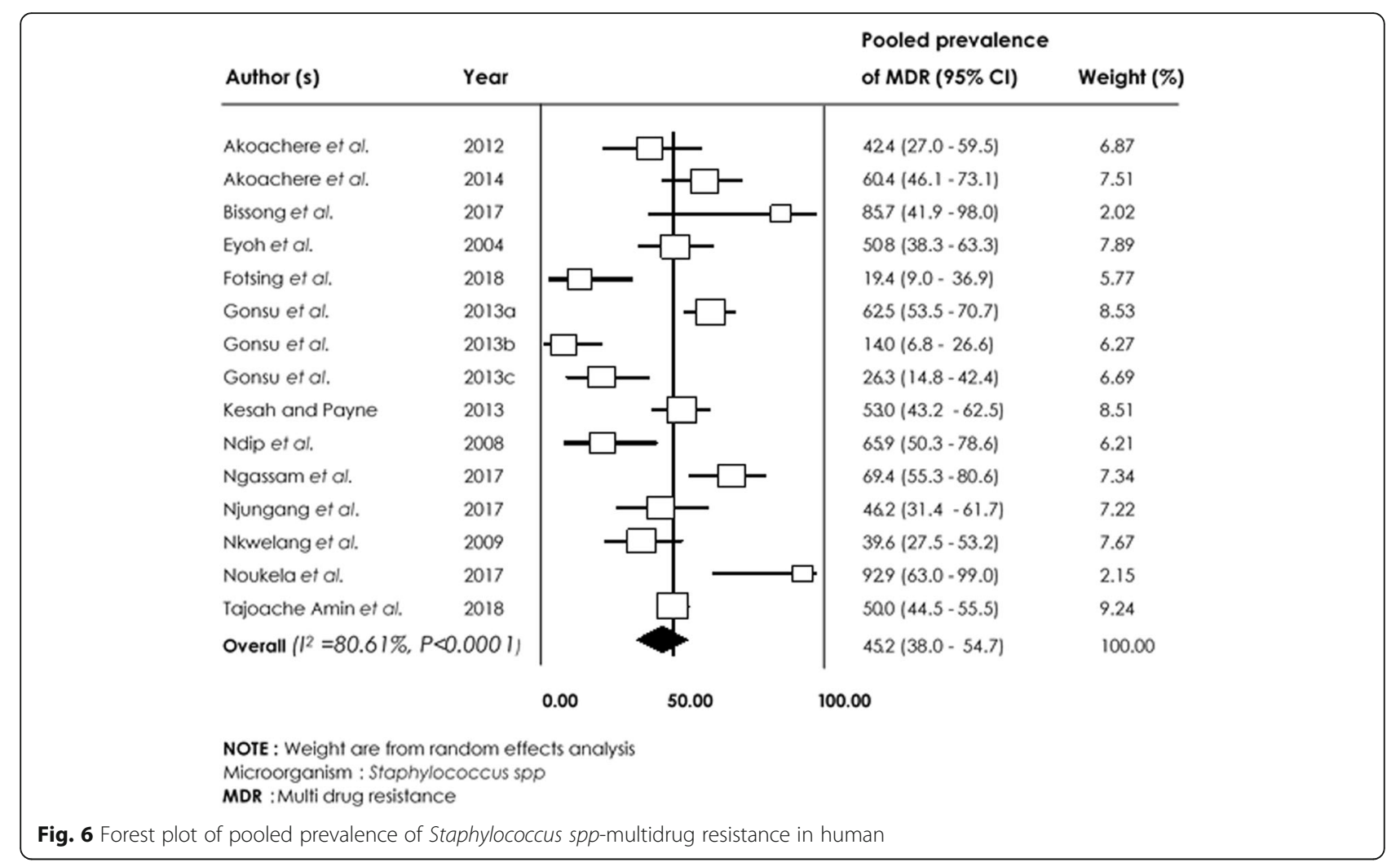

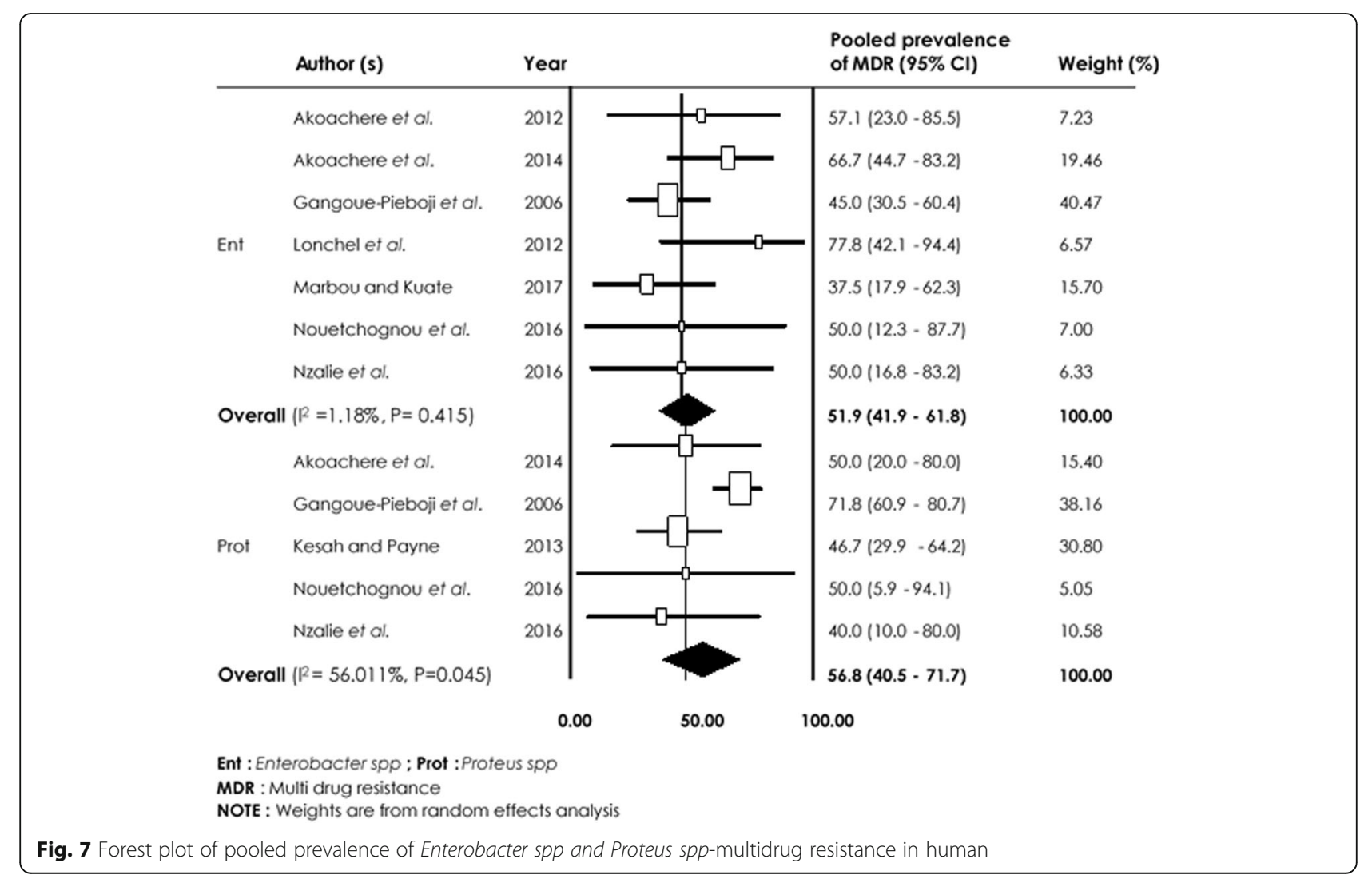


Table 3 Pooled prevalence of Multidrug Resistance of E. coli, Klebsiella spp and Staphylococcus spp- based on meta-analysis of human studies with respect to study area

\begin{tabular}{lllll}
\hline Bacteria mostly reported in studies & Study Area (Region) & Number of studies & Pooled prevalence of AMR (95\% Cl) & $p$ value \\
\hline E. coli & Centre & 6 & $35.9(24.2-49.6)$ & $4.6(35.6-56.0)$ \\
& South-West & 3 & $60.9(33.0-83.2)$ & 0.82 \\
& North-West & 3 & $40.9(28.1-55.0)$ & 0.33 \\
& West & 3 & $45.8(28.3-64.1)$ & 0.61 \\
Klebsiella spp & Centre & 4 & $51.6(38.5-64.5)$ & 0.65 \\
& South-West & 4 & $52.6(30.5-73.7)$ & 0.82 \\
Ntaphylococcus spp & North-West & 2 & $37.9(47.7-67.4)$ & 0.64 \\
& West & 2 & $62.2(18.2-92.4)$ & 0.13 \\
& Centre & 5 & $45.3(36.2-54.7)$ & 0.45 \\
& South-West & 2 & $56.6(32.0-78.4)$ & 0.69 \\
\hline
\end{tabular}

Note: $P$ values are from random effects analysis, AMR: Antimicrobial resistance

resistance is under-investigated and under-reported in the WHO African region including Cameroon $[1,5,11]$ due to limited or unavailability of diagnostic tests and lack of microbiology technical resources. These have led to the inability to test clinical isolates for antimicrobial susceptibility as well as contributed to excessive use and misuse of antibiotics and the phenomenon of AMR. Antibiotic resistant strains may be easily transferred within the human-animal-environment interfaces due to high level of interactions. For example, resistant pathogens in food producing animals and environments can be passed easily to human during various interactions.

Pathogens isolated from food producing animals in the current review such as Salmonella spp and E. coli showed high resistance against ampicillin, amoxicillin, STX, tetracycline and doxycycline. This agrees with reported high antibiotic simple (up to $86 \%$ ) and multidrug (73\%) resistance rates in Africa [88]. Considering that these are typically empiric antibiotics used for strategic health management in human and animals, the preservation of these important antibiotics for human health cannot be overemphasized [89, 90]. The multidrug resistance observed in this study for Salmonella spp and E. coli, could be a consequence of overuse or misuse of antibiotics, failure to consult veterinarians before the antibiotherapy, absence of a clear regulation code on the use of antibiotics in animals $[91,92]$ in Cameroon. The widespread use of substandard drugs [93] and poor hygiene handling of food [94, 95] have been reported earlier in the country. The main route of transmission of drug-resistant strains from food producing animals to humans occur through contamination of edible animal products. Therefore, the misuse of veterinary drugs and misguided therapy in veterinary medicine could select resistant strains in food animals and cause considerable impact on human health [96].

The findings of this review revealed gaps in the surveillance and interdisciplinary sharing of data on the

Table 4 Pooled prevalence of antibiotic resistance of E. coli and Salmonella spp-based on a meta-analysis of animal studies

\begin{tabular}{llll}
\hline Bacteria reported in studies & Antimicrobial agent & Number of studies & Pooled prevalence of AMR (95\% Cl) \\
\hline E. coli & Aminoglycosides & 3 & $38.7(7.8-82.4)$ \\
& Gentamicin & & 8ulfonamides \& Trimethoprim \\
& Trimethoprim/Sulfamethoxazole & 4 & $51.3-96.0)$ \\
Beta-lactams & Amoxicillin & $46.7(8.0-95.2)$ \\
Amoxicillin/Clavulanic acid & 3 & $25.4(10.1-91.7)$ \\
& Tetracyclines & 3 & $85.5(49.9-97.7)$ \\
& Tetracycline & 3 & $68.2(57.2-75.5)$ \\
\hline
\end{tabular}




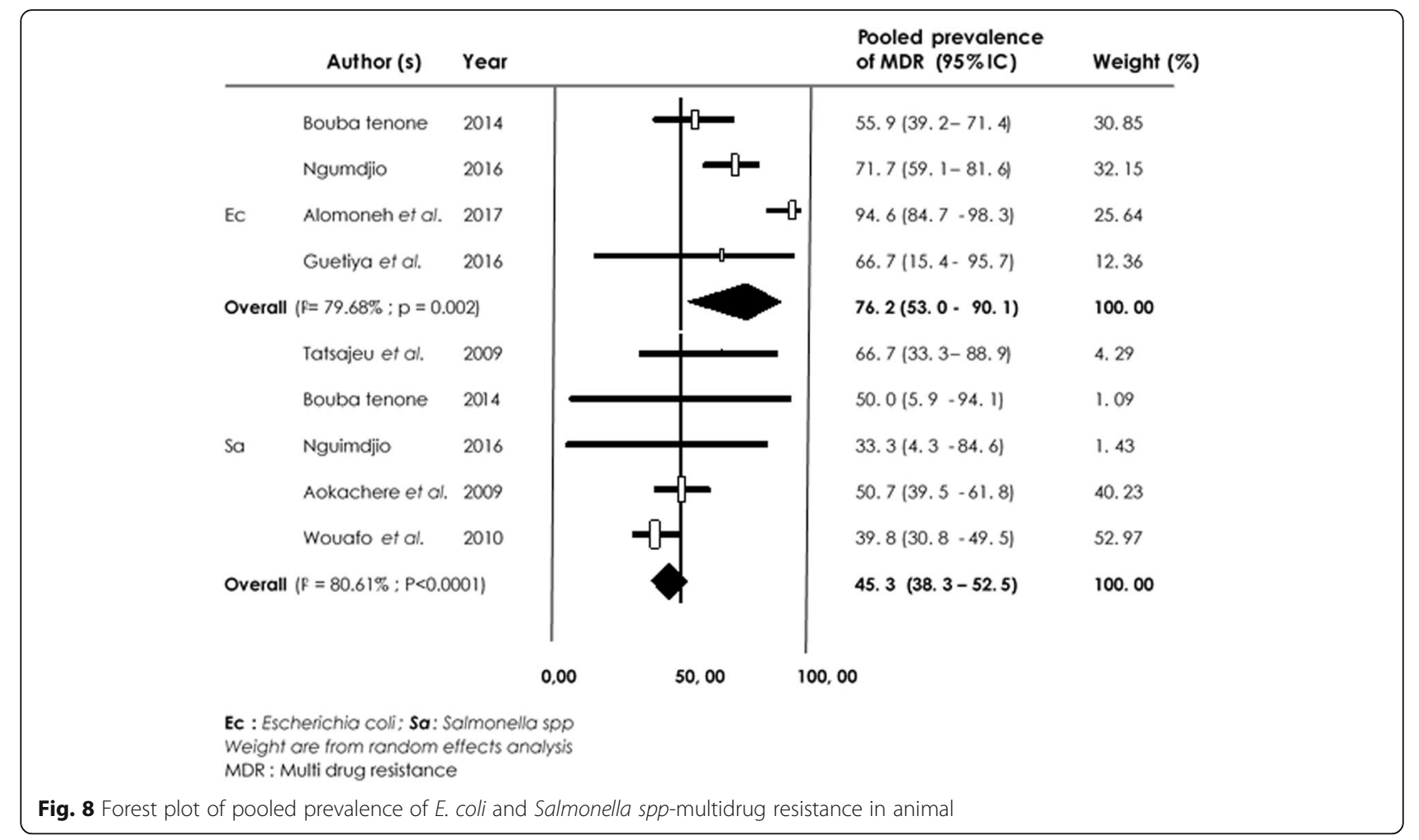

emergence of AMR in foodborne bacteria and their potential impact on both animal and human health in Cameroon. In this context, the One Health Approach for control AMR should include improved integrated surveillance of resistance in bacteria in food-producing animals in the food chain, food products, humans and the environment and prompt sharing of data [96].

Uncontrolled use and/or misuse of antimicrobials (use without prior laboratory susceptibility testing) in agriculture has been linked to increase in the rates of drug resistance $[5,84]$ since contaminating bacteria usually tend to be treated with dosage rates lower than required for the treatment or exposed to an ineffective drug. In this review, Staphylococcus spp, Bacillus spp and Vibrio cholerae isolated from the environment (hospital surfaces and devices, water and abattoirs drain) were highly resistant to the first line antibiotics used in human and animals and showed high multidrug resistance rates. Poor hygiene of hospital surfaces and inadequate management of expired drugs could be responsible for the high AMR rates. Easy transmission of resistant bacteria from the environment to humans and animals also play a role in the highly resistant Staphylococcus spp reported in human studies and most of these inappropriately used antimicrobials often end up in wastewater in low and middle-income countries including Cameroon as previously reported [97]. Drug-resistant pathogens have higher chances of surviving and emerging when they are found in sewage. Also, antibiotic-resistant bacteria in the environment may be due to the dynamism and acquisition of antibiotic resistance genes that can be transferred horizontally from one bacteria to another [3]. This could explain high relationship between resistance in the environmental studies and overuse and uncontrolled use of antimicrobials in human and animal medicine since part of the drugs are excreted or secreted in the environment [3].

The current review also highlights lack of published AMR data on human, animal and environmental health in three, six and seven regions in Cameroon, respectively. Bridging the knowledge gaps and enhancing AMR surveillance in Cameroon to reduce the threat of AMR on public health cannot be overemphasised. As part of the global One Health Strategic plan against public threats and enhance the Global Antimicrobial Resistance Surveillance System [20], Cameroon has instituted a National Action Plan to fight against Antimicrobial Resistance (NAP-RAM 2018-2020) [98] to reduce the burden of AMR in the country. The plan is multisectoral involving seven key ministerial departments and technical partners and has six major objectives: (1) to improve awareness and understanding of antimicrobial resistance through effective communication, education and training; (2) to strengthen knowledge and evidence through monitoring and research; (3) to reduce the incidence of infections by applying effective sanitation, hygiene and infection control measures; (4) to optimize the use of antimicrobials in human, animal and plant health; (5) to 
Table 5 Pooled prevalence of antibiotic resistance of Bacillus spp, Staphylococcus spp and Vibrio cholerae-based on the meta-analysis of environmental studies

\begin{tabular}{|c|c|c|c|}
\hline Bacteria reported in studies & Antimicrobial agents & Number of studies & Pooled prevalence of AMR $(95 \% \mathrm{Cl})$ \\
\hline \multirow[t]{18}{*}{ Bacillus spp } & Beta-lactams & & \\
\hline & Amoxicillin & 4 & $83.8(59.5-94.8)$ \\
\hline & Amoxicillin+Clavulanic acid & 3 & $65.9(48.3-80.0)$ \\
\hline & Penicillin & 4 & $64.8(34.2-86.7)$ \\
\hline & Oxacillin & 3 & $81.1(64.8-90.9)$ \\
\hline & Ceftazidime & 3 & $53.4(30.4-75.1)$ \\
\hline & Cefuroxime & 3 & $70.1(50.6-84.2)$ \\
\hline & Cefoxitine & 3 & $88.7(74.5-95.5)$ \\
\hline & Ceftriaxone & 3 & $61.7(29.9-85.9)$ \\
\hline & Aminoglycosides & & \\
\hline & Gentamicin & 3 & $14.0(6.6-27.1)$ \\
\hline & Quinolones & & \\
\hline & Nalidixic acid & 3 & $45.2(20.8-72.3)$ \\
\hline & Ciprofloxacin & 3 & $28.1(23.9-32.8)$ \\
\hline & Nitrofuranes & & \\
\hline & Nitrofurantoin & 3 & $60.4(48.5-71.2)$ \\
\hline & Sulfonamides \& Trimethoprim & & \\
\hline & Co-trimoxazole & 3 & $61.6(38.1-80.7)$ \\
\hline \multirow[t]{15}{*}{ Staphylococcus spp } & Beta-lactams & & \\
\hline & Amoxicillin & 4 & $67.2(31.1-90.3)$ \\
\hline & Amoxicillin+Clavulanic acid & 3 & $59.6(47.5-70.6)$ \\
\hline & Penicillin & 5 & $78.3(54.3-91.9)$ \\
\hline & Oxacillin & 3 & $89.3(84.2-92.9)$ \\
\hline & Ceftazidime & 3 & $69.5(52.0-82.7)$ \\
\hline & Cefoxitine & 3 & $74.7(62.3-84.1)$ \\
\hline & Ceftriaxone & 3 & $83.8(68.4-92.5)$ \\
\hline & Quinolones & & \\
\hline & Nalidixic acid & 3 & $89.1(83.7-92.8)$ \\
\hline & Ciprofloxacin & 4 & $18.2(5.9-44.3)$ \\
\hline & Nitrofuranes & & \\
\hline & Nitrofurantoin & 3 & $44.7(37.9-51.7)$ \\
\hline & Sulfonamides \& Trimethoprim & & \\
\hline & Co-trimoxazole & 3 & $62.1(32.4-84.9)$ \\
\hline \multirow[t]{6}{*}{ Vibrio cholerae } & Beta-lactams & & \\
\hline & Ampicillin & 4 & $53.6(47.3-59.8)$ \\
\hline & Phenicols & & \\
\hline & Chloramphenicol & 4 & $19.1(2.4-69.0)$ \\
\hline & Tetracyclines & & \\
\hline & Tetracycline & 4 & $41.60(14.6-74.9)$ \\
\hline
\end{tabular}

AMR Antimicrobial resistance

develop economic arguments for sustainable investments and the production of new medicines, diagnostic tools, vaccines and other interventions for the fight against
AMR; (6) to improve governance in the sector through strengthening of standardization, regulation and accountability. Effective implementation of the actual 


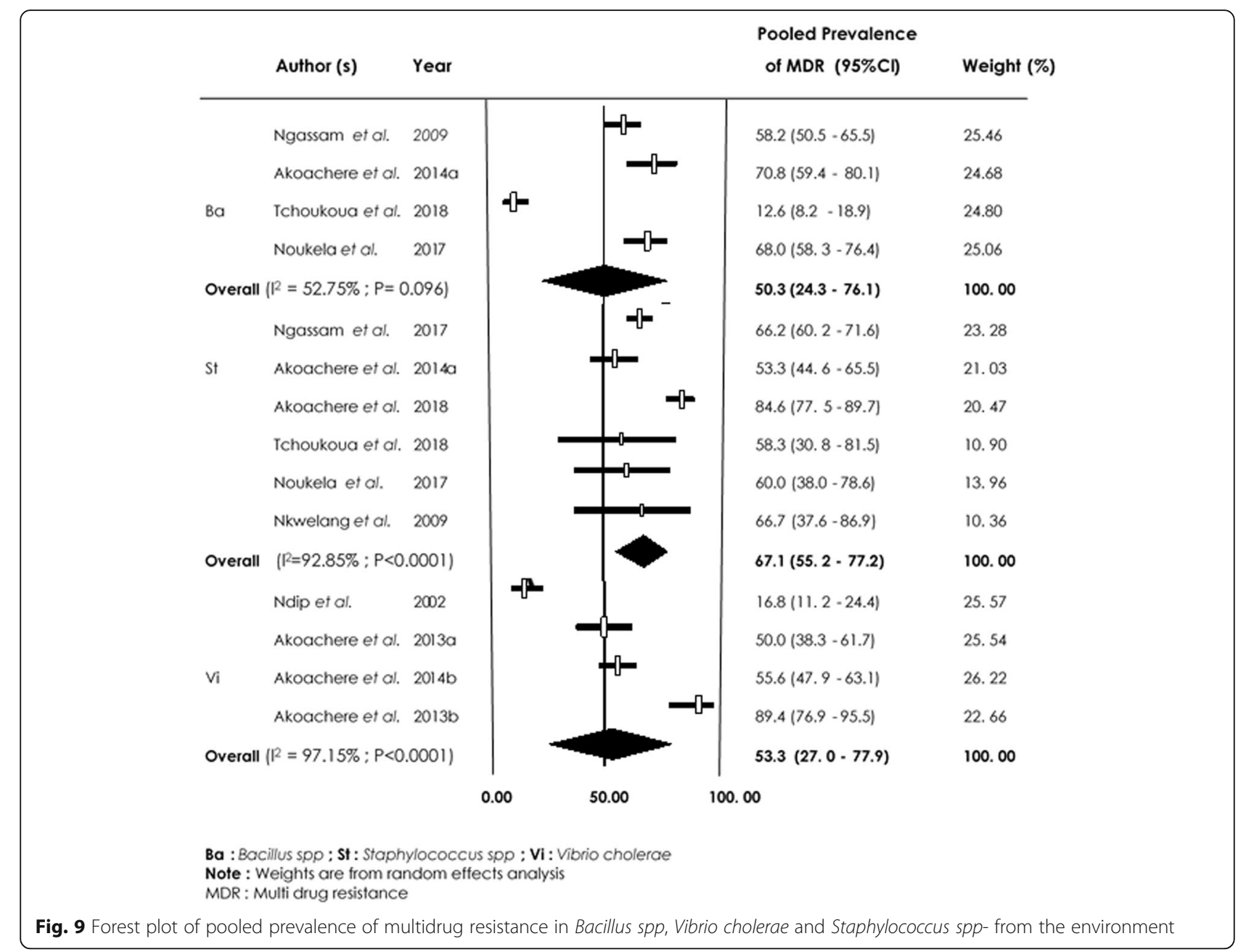

national action plan according to the "One Health" concept could be a reliable effort to reduce the burden of AMR at the national level. However, certain barriers for implementation exist including as poverty, remote nature of many rural zones and risk of emerging diseases. In addition, the lack of experts trained in 'One Health Approach' and the inadequacy of curriculum of educational programs regarding antimicrobial prescription, use and AMR could constitute other limitations to the application of this current plan.

This review does not only give an estimate of the level of AMR in Cameroon but revealed large knowledge gaps. Short comings were related to the representativeness of data which focused on AMR reports which did not support evaluation since absence of resistance cases were not routinely declared. Existing data were concentrated on four regions of the country. Also, very few reports from animal and environment were available. A further limitation is combining AMR results from different patient groups across different regions of the country to compare. The high-level resistance rates observed could be due to the approach used. Nonetheless, the review revealed the general trend and developments of AMR. Finally, for the purpose of this review, resistance data gotten using laboratory methodologies were combined. Variation in AMR methodology has minimal effect on the quality of final results and many studies used the disk diffusion method and CLSI guidelines [1]. Intense therapeutic studies will highlight further knowledge on the clinical impact of AMR and disadvantages of strategies that rely on empirical use of broaderspectrum drugs. The emergence of AMR in Cameroon is a real threat that cannot be ignored.

\section{Conclusion}

The present review highlights the high prevalence of resistance to commonly used antibiotics in humans, animals and the environment in Cameroon. Multi-drug resistance was observed to be a real and rising threat. All bacteria isolated showed resistance to more than one drug of choice in different or similar drug lines. In the Cameroon context where infectious diseases are highly 
endemic, there is insufficient data from interventional studies in the struggle to contain AMR. Given that there is dearth of data on hospital, community-acquired infections, animal infections and prevalence of AMR in Cameroon, systemic investigations and surveillance cannot be overemphasized. Long-lasting measures encouraging the implementation of antimicrobial stewardship in Cameroon such as pharmacy, laboratory quality control, full microbiology investigations and the development and distribution of standard antibiograms nationwide should be reinforced. Public health education on prescription, sensitization of users and elaboration of stringent drug regulations and fight against counterfeit drugs are essential to reduce AMR in Cameroon. The national action plan to reduce the burden of AMR can succeed only through continued data sharing as well as global collaboration, harmonization, and coordination between all partners involved in the implementation of AMR surveillance.

\section{Abbreviations}

AMR: Antimicrobial Resistance; Cl: Confidence Interval; GLASS: Global Antimicrobial Resistance Surveillance System; MDR: Multidrug Resistance; PRISMA: Preferred Reporting Items for Systematic Reviews and MetaAnalyses; WHO: World Health Organization

\section{Acknowledgements}

The authors are grateful for the generation contribution of additional information received from the authors of articles used for this review study. This study was benefited from intellectual contributions from the PREDICT staff project (GHN-A-OO-09-00010-00). The datasets used and analyzed during this review study were provided by the corresponding authors upon reasonable request.

\section{Authors' contributions}

MMMM and FM conceived and designed the study. FM, MMMM, JFTKA, NHON, FFDT and NPM coordinated the literature search with the guidance of JAN. JAN, JFTKA, MMMM and FM designed data collections tools. FM, MMMM and NPM undertook data extraction, quality assessment and statistical analysis. FM, MMMM and NHON prepared the first draft of the manuscript. JAN, JFTKA, VNN, AW, DGTT, JMKF, ML and HRZ critically reviewed the manuscript. All authors read and approved the final version of the manuscript.

\section{Funding}

No specific funding was received for this study.

Availability of data and materials

Not applicable.

\section{Ethics approval and consent to participate}

Not applicable.

\section{Consent for publication}

Not applicable.

\section{Competing interests}

The authors declare that they have no competing interests regarding the publication of this paper.

\section{Author details}

${ }^{1}$ Department of Pharmacy, Pharmacology and Toxicology, School of Veterinary Medicine and Sciences, University of Ngaoundéré, Ngaoundéré, Cameroon. ${ }^{2}$ MOSAIC, Yaoundé, Cameroon. ${ }^{3}$ Laboratory of Animal Physiology and Health, Department of Zootechnics, Faculty of Agronomy and Agricultural Sciences, University of Dschang, Dschang, Cameroon. ${ }^{4}$ Department of Microbiology and Parasitology, Faculty of Science, University of Buea, Buea, Cameroon. ${ }^{5}$ Institute of Agricultural Research for Development, Veterinary Research Laboratory, Wakwa Regional Center, Ngaoundéré, Cameroon. 'Johns Hopkins Cameroon Program, Yaoundé, Cameroon. ${ }^{7}$ National Veterinary Laboratory (LANAVET), Yaounde, Cameroon.

${ }^{8}$ Faculty of Heath Science, Université des Montagnes, Bangangté, Cameroon. ${ }^{9}$ National Public Health Laboratory (LNSP), Yaounde, Cameroon.

${ }^{10}$ Epidemiology-Public Health-Veterinary Association (ESPV), Yaounde, Cameroon. ${ }^{11}$ Cameroon Epidemiological Network for Animal Diseases (RESCAM), Ministry of Livestock, Fisheries and Animal Industries (MINEPIA), Yaoundé, Cameroon. ${ }^{12}$ College of Technology, University of Bamenda, Bambili, Cameroon.

Received: 9 March 2019 Accepted: 6 August 2019

Published online: 19 August 2019

References

1. Tadesse TB, Ashley AE, Ongarello S, Havumaki J, Wijegoonewardena M, González JI, Dittrich S. Antimicrobial resistance in Africa: a systematic review. BMC Infect Dis. 2017;17:616. https://doi.org/10.1186/s12879-1201 7-12713-12871.

2. Tang LK, Caffrey PN, Nóbrega BD, Cork CS, Ronksley EP, Barkema WH, Polachek JA, Ganshorn H, Sharma N, Kellner DJ, et al. Restricting the use of antibiotics in food-producing animals and its associations with antibiotic resistance in food-producing animals and human beings: a systematic review and meta-analysis. Lancet Planet Health. 2017;1:316-27.

3. Bougnom PB, Piddock JL. Wastewater for urban agriculture. A significant factor in dissemination of antibiotic resistance. Environ Sci Technol. 2017;51:5863-4.

4. Ampaire $L$, Muhindo A, Orikiriza $P$, Mwanga-Amumpaire J, Bebell L, Boum Y. A review of antmicrobial resistance in East Africa. Afr J Laby Med. 2016;5(1): 432. https://doi.org/10.4102/ajlm.v5i41.432.

5. WHO. «Antimicrobial resistance » Bull World Health Org. 2014; 61. doi: https://doi.org/10.1007/s13312-13014-10374-13313.

6. WHO. WHO guidelines on use of medically important antimicrobials in food-producing animals. Geneva: World Health Organization; 2017. p. 88. Licence: CC BY-NC-SA 83.80 IGO

7. Alonso CA, Zarazaga M, Ben Sallem R, Jouini A, Ben Slama K, Torres C. Antibiotic resistance in Escherichia coli in husbandry animals: the African perspective. Let Applied Microbiol. 2017;64:318-34.

8. OIE. Annual report on antimicrobial agents intended for the use in animals: Better understanding of the global situation, Second report, Paris, France; 2017. p. 125

9. Akoachere TKJF, Tatsinkou FB, Nkengfack MJ. Bacterial and parasitic contaminants of salad vegetables sold in markets in Fako division, Cameroon and evaluation of hygiene and handling practices of vendors. BMC Res Notes. 2018;11:100. https://doi.org/10.1186/s13104-018-3175-2.

10. Bernabé KJ, Langendorf C, Ford N, Ronat J-B, Murphy AR. Antimicrobial resistance in West Africa: a systematic review and meta-analysis. Int J Antimicrob Agents. 2017:50:629-39.

11. Essack SY, Desta AT, Abotsi RE, Agoba EE. Antimicrobial resistance in the WHO African region: current status and roadmap for action. J Pub Health. 2016;39:38-13. https://doi.org/10.1093/pubmed/fdw1015.

12. Thanner S, Drissner D, Walsh F. Antimicrobial Resistance in Agriculture. mBio. 2016;7(2):02227-15.

13. OHCEA. Knowledge, Attitides and Pratices survey on Antimicrobial resistance in Cameroon: Investigation Report. Yaoundé: OHCEA-Cameroon; 2017, p.1-37.

14. Ayukekbong JA, Ntemgwa M, Atabe NA. The threat of antimicrobial resistance in developing countries: causes and control strategies. Antimicrob Res Infect Cont. 2017;6:47. https://doi.org/10.1186/s13756-13017-10208-X.

15. Ngassam TR, Tantse M, Fotsing KP, Noukela Noumi D, Kouamouo J, Simo Louokdom DG, Tchoukoua SO, Kweyang TB, Kourouma K. Multicenter study on antibiotic susceptibility/resistance trends in the western region of Cameroon. Int J Biol Chem Sci. 2017;11(11):131-43.

16. Tchoukoua SO, Fotsing Kwetché PR, Tchami NF, Gamwo Dongmo S, Nguekap NW, Yawat Djogang AM, Simo Louokdom J, Kouamouo J, Kourouma K. Observance of guilinses towards mitigating the risk of hospital acquired infections in a university teaching hospital: preliminary findings from a pilot study towards healthcare quality improvement. World J Adv Healthcare Res. 2018;2(4):204-12.

17. Manishimwe R, Nishimwe K, Ojok L. Assessment of antibiotic use in farm animals in Rwanda. Trop Anim Health Prod. 2017:49:1101-6. https://doi. org/10.1007/s11250-11017-11290-z. 
18. Moher D, Liberati A, Tetzlaff J, Altman D, Group PRISMA. Preferred reporting items for systematic reviews and meta-analyses: the PRISMA statement. PLoS Med. 2009;6:e1000097.

19. Naylor RN, Silva S, Kulasabanathan K, Atun R, Zhu N, Knight MG, Robotham J. Methods for estimating the burden ofantimicrobial resistance: a systematic literature review protocol. Sys Rev. 2016;5:187. https://doi.org/1 0.1186/s13643-13016-10364-13648.

20. WHO. Global antimicrobial resistance surveillance system (GLASS) report: early implementation 2016-2017. Geneva: World Health Org; 2017. Licence: CC BY-NC-SA 3.0 IGO. p. 164

21. Munn Z, Mool S, Riitano D, Lisy K. The development of a critical appraisal tool for use in systematic reviews addressing questions of prevalence. Int J Health Policy Manag. 2014;3:123-8.

22. Crowther M, Wendy Lim W, Crowthe AM. Systematic review and metaanalysis methodology. Blood. 2010;116(117):3140-6.

23. Begg CB, Mazumdar M. Operating characteristics of a rank correlation test for publication bias. Biometrics. 1994;50:1088-101.

24. Egger M, Davey SG, Schneider M, Minder C. Bias in meta-analysis detected by a simple, graphical test. BMJ. 1997;315:629-34.

25. Duval S, Tweedie R. Trim and fill: a simple funnel-plot-based method of testing and adjusting for publication bias in meta-analysis. Biometrics. 2000; 56:455-63.

26. Stroup DF, Berlin JA, Morton SC, Olkin I, Williamson GD, Rennie D, Moher D, Becker JB, Ann Sipe T, Thacke BT. Meta-analysis of observational studies in epidemiology. JAMA. 2000;283(15):2008-12.

27. Adawaye C, Toukam M, Assam J, Nkoa T, Gonsu H. Koanga, Koulla Shiro S. vaginal colonization and resistance profile of group B streptococcus among pregnant women in yaounde Genycology, obstetric and pediatric hospital in Cameroon. J Clin Med Res. 2014;6(3):16-21.

28. Adiogo D, Ngum Ze V, Beyala F, Gonsu KH, Okomo Assoumou M, Beyiha G. Importance of Bacterial Resistance in Streptococcus pneumoniae and Streptococcus pyogenes in the Center Region in Cameroon. Afr J Pat Microbiol. 2013;2(3). https://doi.org/10.4303/ajpm/235642.

29. Akoachere JTK, Palle JN, Mbianda SE, Nkwelang G, Ndip NR. Risk factors for wound infection in health care facilities in Buea, Cameroon: aerobic bacterial pathogens and antibiogram of isolates. PanAfr Med J. 2014;18:16. https://doi.org/10.11604/pamj.12014.11618.11606.12304.

30. Akoachere JTK, Suylika Y, Njom HA, Esemu NS. Etiologic profile and antimicrobial susceptibility of community-acquired urinary tract infection in two Cameroonian towns. BMC Res Notes. 2012;5:219.

31. Ateba N, Ngaba G, Okalla Ebongue C, Ngassongo R, Tsiagadigui J, Behiya G, Nguep E, Adiogo D. Susceptibility to Colistin of Multi-Resistant Pseudomonas aeruginosalsolated in Douala Laquintinie Hospital, Cameroon. Afr J Pat Microbiol. 2013;2(4). https://doi.org/10.4303/ajpm/235641.

32. Ateudjieu J, Beyala Bita'a L, Guenou E, Chebe A, Chukuwchindun B, Goura A, Bisseck AZ. Profil et antibiosensibilité des bactéries pathogènes associées aux diarrhées chez les patients consultant à l'Hôpital Régional Annexe de Kousseri, Extrême-Nord Cameroun. PanAfr Med J. 2018;29:170. https://doi. org/10.11604/pamj.12018.11629.11170.14296.

33. Bissong MEA, Mbah C, Tatsing Foka F, Kamga HL. Spectrum of Uropathogens and antimicrobial susceptibility in clinically diagnosed cases of urinary tract infection in the Bamenda regional hospital, Cameroon. Am J Health Res. 2017;5(2):19-24.

34. Chiabi A, Djoupom M, Mah E, Nguefack S, Mbuagbaw L, Zafack J, Ghoyap M, Nkoa Tchokoteu PFT. The clinical and Bacteriogical Spectrum of neonatal Sepsis in a tertiary Hospital in Yaounde, Cameroon. Iran J Ped. 2011;21(24):441-8.

35. Dehayem M, Ngassam E, Mendane F, Balla V, Saji J, Sobngwi E, Mbanya JC. OP67 Bacteriology of diabetic foot infections and susceptibility to antimicrobial agents in Cameroon. Diabetes Res Clin Pratice. 2014;103(1):S27.

36. Djuikoue I, Njajou O, Gonsu KH, Fokunang C, Bongoe A, Ela Ondo B, Tadjoung P, Linjouom A, Kakam C, Ngogang J. Prevalence of CTX-M betaLactamases in Escherichia coli from community-acquired urinary tract infections and associated risk factors among women in Cameroon. J Epidemiol Res. 2017;3(1). https://doi.org/10.5430/jer.v5433n5431p5451.

37. Eyoh AB, Toukam M, Atashili J, Fokunang C, Gonsu K, Lyonga EE, Henshaw M, Ikomey G, Mukwele B, Mesembe M, et al. Relationship between multiple drug resistance and biofilm formation in Staphylococcus aureus isolated from medical and non-medical personnel in Yaounde, Cameroon. PanAfr Med J. 2014;17:186. https://doi.org/1 0.11604/pamj.12014.11617.11186.12363.
38. Fotsing Kuetche PR, Kouamouo J, Mbaya P, Yangoué D, Nsangou A, Wona J, Simo Louokdom J, Kourouma K, Kaptué L. Antibiotic resistance in Escherichia coli isolated from women genitalia and trend of minimal inhibiting concentration in a semi-urban population: Bangangté, WestCameroon. Cur Res J Biol Sci. 2012;4(6):696-701.

39. Fotsing Kwetche PR, Louokdom S, Kamga C, Kaba K, Kouamouo J. $\beta$ lactamase-associated resistance phenotypes amongst multidrug resistant bacteria isolated in a school hospital of West Cameroon. Int J British. 2015; 2(4):59-70.

40. Fotsing Kwetche PR, Nankam Nguekap WL, Domngang Noche C, Djogang YAM, Gamwo S, Louokdon SJ, Towo CE, Tchoukoua SH, Kouamouo J. Kaba Kourouma: specimens and gram-negative bacteria etiologies of infectious diseases in a semi-urban area in West-Cameroon: a twelve-month rundown of infection screening in the medical school teaching hospital. World J Phar Life Sci. 2018:4(2):188-94.

41. Gonsu KH, Toukam M, Ndze VN, Koulla SS. Nasal carriage of methicillin resistant Staphylococcus aureus and its antibiotic susceptibility pattern in adult hospitalized patients and medical staff in some hospitals in Cameroon. J Microbiol Antimicrob. 2013;5(3):29-33.

42. Gonsu KH, Epée E, Matalom C, Ngobo A, Toukam M, Sando Z, Moukouri E. Profil Bactériologique et Sensibilité aux Antibiotiques des Germes isolés des infections de la Surface Oculaire à Yaoundé. Health Sci Dis. 2013;14(4):1-5.

43. Gonsu KH, Ndongo GA, Adiogo D, Toukam M, Ndze VN, Kechia AF, Nkam M. Carriage of multi-drug resistant bacteria among medical staff of the Yaoundé University teaching hospital, Cameroon. J Bacteriol Res. 2013;5(5): 62-7.

44. Gonsu KH, Nzengang R, Toukam M, Sando Z, Koulla Shiro S. Phenotypes de réesistance des souches d' Escherichia coli responsables des infections urinaires communautaires dans la ville de Yaounde. Afr J Pathol Microbiol. 2014;3. https://doi.org/10.4303/ajpm/235891.

45. Gonsu KH, Sango Gueye M, Toukam M, Mbassi A, Kengne M, Adiogo D. Résistance aux antibiotiques des entérocoques responsables des infections urinaires au Centre Hospitalier et Universitaire et à l'Hôpital Central de Yaoundé (Cameroun). Afr J Pathol Microbiol. 2015;4. https://doi.org/10.4303/ ajpm/235913.

46. Gangoue-Pieboji J, Bedenic B, Randegger C, Adiogo D, Koulla Shiro S, Ngassam P, Ndumbe P, Hachler H. Extended-spectrum-b-lactamaseproduicing Enterobacteriaceae in Yaounde, Cameroon. J Clin Microbiol. 2005;42(47):3273-7.

47. Gangoue-Pieboji J, Koulla Shiro S, Ngassam P, Adiogo D, Ndumbe P. Antimicrobial activity against gram negative bacilli from Yaounde central hospital, Cameroon. Afr Health Sci. 2006;6(4):232-5.

48. Gangoue-Pieboji J, Koulla Shiro S, Ngassam P, Adiogo D, Njine T, Ndumbe P. Antimicrobial resistance of gram-negative bacilli isolates from inpatients and out-patients at Yaounde central hospital, Cameroon. Int J Inf Dis. 2004; 8:147-54.

49. Kesah CF, Khan PV. Antimicrobial resistance in Dschang. Cameroon Ann Trop Med Pub Health. 2013;6(4):446-51.

50. Lonchel CM, Meex C, Gangoué-Piéboji J, Boreux R, Okomo Assoumou M, Melin P, De Mol P. Proportion of extended-spectrum B-lactamaseproducing Enterobacteriaceae in community setting in Ngaoundere, Cameroon. BMC Infect Dis. 2012;12:53.

51. Longla ME, Lyonga-Mbamyah EE, Kalla GC, Abange Baiye W, Chafa BA Gonsu KH. Evolution Profile of Escherichia coli Resistance from January 2009-April 2013 to Antibiotics at the Yaounde University Teaching Hospital, Cameroon. British Microbiol Res J. 2016;17(15). https://doi.org/10.9734/ BMRJ/2016/29416.

52. Louokdom SJ, Fotsing Kwetche PR, Kouamouo J, Kengne Toam AL, Gamwo Dongmo GS, Tchoukoua SH, Tamatcho Kweyang BP, Kuiaté JR. High antibiotic resistance in Bacteria from a healthcare setting: case in the surgery wards of the regional Hospital of Bafoussam, West-Cameroon. J Chem, Biol and Phy Sci. 2016;6(4):1297-307.

53. Lyonga E, Toukam M, Atashili J, Gonsu H, Adiogo D, Mesembe M, NguefackTsague G, Eyoh A, Ikomey G, Mukwele B, et al. A Comparative Study on Susceptibility of Enterobacteriaceae to Six Quinolones in Yaounde. Health Sci Dis. 2013;14(4):1-7.

54. Lyonga EE, Toukam M, Nkenfou C, Gonsu KH, Assoumou OM, Mesembe TM, Eyoh BA, Ikomey MG, Ngum Ndze V, Koulla-Shiro S. Resistance pattern of enterobacteriaceae isolates from urinary tract infections to selected quinolones in Yaoundé. Pan Afr Med J. 2015;21(105). https://doi.org/10.116 04/pamj.12015.11621.11105.15469. 
55. Marbou WJT, Kuete V. Bacterial resistance and immunological profiles in HIV-infected and non-infected patients at Mbouda AD LUCEM Hospital in Cameroon. J Infect Pub Health. 2017;10:269-76.

56. Ndip NR, Titanji V, Akenji V, Mutanga A, MBatcham W, Ndip LM. Antibiobiogram of Klebsiella pneumonae isolates from Buea, Cameroon. Cent Afr J Med. 2001:47(47):173-6.

57. Ndip NR, Takang EMA, Ojongokpoko AEJ, Luma NH, Malongue A, Akoachere TKJ-F, Ndip ML, MacMillan M, Weave TL. Helicobacter pylori isolates recovered from gastric biopsies of patients with gastro-duodenal pathologies in Cameroon: current status of antibiogram. Tropical Med Int Health. 2008;13(16):848-54

58. Ndip RN, Dilonga HM, Ndip LM, Akoachere TJ-F, Nkuo AT. Pseudomonas aeruginosa isolates recovered from clinical and environmental samples in Buea, Cameroon: current status on biotyping and antibiogram. Tropical Med Int Health. 2005;10(11):74-81.

59. Ndip RN, Ntiege EA, Ndip LM, Nkwelang G, Akoachere J-FTK. Nkuo Akenji. Antimicrobial resistance of bacterial agents of the upper respiratory tract of school children in Buea, Cameroon. J Health Popul Nutr. 2008;26(24):397-404

60. Njoungang L, Nwobegahay MJ, Ayangma CR, Njukeng AP, Kengne M, Mbozo'o Abeng E, Mama E, Tchouamo M, Ter Goon D. Prevalence and antibiotic resistance patterns of strains of Staphylococcus aureus isolated at the Yaounde military hospital, Cameroon. Microbiol Res Int. 2015;3(4):56-63.

61. Njunda LA, Assob CJ, Nsagha SD, Kamga LH, Awafong PM, Weledji PE. Epidemiological, clinical features and susceptibility pattern of shigellosis in the Buea Health District, Cameroon. BMC Res Notes. 2012;5:54.

62. Nkembe NM, Gonsu KH, Baiye AW, Chafa BA, Njotang NP. Streptococcus agalactiae prevalenceand antimicrobial susceptibility pattern in vaginal and anorectal swabs of pregnant women at a tertiary hospital in Cameroon. BMC Res Notes. 2018;11:480. https://doi.org/10.1186/s13104-13018-13589-x.

63. Nkwelang G, Akoachere TKJ-F, Kamga HL, Nfoncham DE, Ndip N. R. Staphylococcus aureus isolates from clinical and environmental samples in a semi-rural area of Cameroon: phenotypic characterization of isolates. Afr J Microbiol Res. 2009;3(11):731-6.

64. Nouetchognou JS, Ateudjieu J, Jemea B, Mesumbe NE, Mbanya D. Surveillance of nosocomial infections in the Yaounde University Teaching Hospital, Cameroon. BMC Res Notes. 2016;9:505. https://doi.org/10.1186/ s13104-13016-12310-13101.

65. Noukela Noumi DP, Fotsing Kwetche PR, Kouamouo J, Simo Louokdom J, Gamwo Dongmo S, Kengne Toam AL, Tchoukoua SH, Tamatcho Kweyang BP, Kourouma K. Bacillus spp. and Staphylococcus spp: potential reservoirs of resistance traits in a healthcare facility. J Chem, Biol Phy Sci. 2016;7(1):037-48.

66. Nzalie NR, Gonsu KH, Koulla-Shiro S. Bacterial etiology and antibiotic resistance profile of community-acquired urinary tract infections in a Cameroonian City. Int J Microbiol. 2016. https://doi.org/10.1155/2 $016 / 3240268$

67. Okalla Ebongue C, Mengue E, Nda Mefo'o J, Tsiazok DR, N'guessan Kouassi R, Ngo BE. Antimicrobial multi-resistance of Acinetobacter baumanii isolated from clinical specimens in Douala, Cameroon. J Dis Med Plants. 2015;1(2):31-6.

68. Tajoache Amin E, Njumkeng C, Kika B, Fualefac A, Njukeng P. Pattern of antimicrobial resistance among bacterial isolates from urogenital clinical specimens. A descriptive study from the Buea Health District, Cameroon. Drugs -Real World Outcomes. 2018;5:101-8.

69. Toukam M, Lyonga EE, Assoumou MCO, Fokunang CN, Atashili J, Kechia AF, Gonsu KH, Mesembe M, Eyoh A, Ikomey G, et al. Quinolone and fluoroquinolone resistance in Enterobacteriaceae isolated from hospitalised andcommunity patients in Cameroon. J Medicine Med Sci. 2010;1(10):490-4

70. Akoachere JTK, Tanih FN, Ndip LM, Ndip NR. Phenotypic characterization of Salmonella typhimurium isolates from food-animals and abattoir drains in Buea, Cameroon. J Health Popul Nutr. 2009;27(25):612-8.

71. Akomoneh AE, Esemu NS, Nfor KG, Ndip NR, Ndip LM. Phenotypic and genotypic antimicrobial resistance profiles of Escherichia coli 0157 isolates from cattle in Cameroon. Int J Trop Dis Health. 2018;31(32):31-10.

72. Bouba TE. Prévalence et facteurs de risque de la colibacillose et des salmonelloses aviaires dans la ville de Ngaoundéré. These Med Vet: ESMV, University de Ngaoundere-Cameroun; 2014. p. 66.

73. Founou L, Founou R, Essacka S, Djoko FC. Mannitol-fermenting methicillinresistant staphylococci (MRS) in pig abattoirs in Cameroon and South Africa: a serious food safety threat. Int J Food Microbiol. 2018;285:250-60.

74. Guetiya Wadoum R, Zambou N, Anyangwe F, Njimou J, Coman M, Verdenelli M, Cecchini C, Silvi S, Orpianesi C, Cresci A, et al. Abusive use of antibiotics in poultry farming in Cameroon and the public health implications. Bri Poul Sci. 2016. https:/doi.org/10.1080/00071668.00072016.01180668.

75. Ndip NR, Akoachere TJ-F, Mokosso D, Ndip LN, Anyangwe F. Carriage of Vibrio species by shrimps harvested from the coastal waters of south West Cameroon. East Afr Med J. 2002;79(73):146-9.

76. Nguimdjio KL. Prévalence et profils de résistance aux antibiotiques des Salmonella spp et Escherichia coli isolé en élevage avicole dans les régions du Centre et de l'Ouest, Cameroun. Thèse Med Vet: ESMV, Université de Ngaoundéré-Cameroun; 2016. 99.

77. Tatsadjieu NL, Kemgang ST, Mbofung CM. Impact de l'utilisation des antibiotiques sur la sensibilité des bactéries pathogènes de poules dans la ville de Ngaoundéré Cameroon. J Exp Biol. 2009;5:52-61.

78. Wouafo M, Nzouankeu A, Kinfack AJ, Fonkoua M-C, Ejenguele G, Njine T, Ngandjio A. Prevalence and Antimicrobial Resistance of Salmonella Serotypes in Chickens from Retail Markets in Yaounde, Cameroon. Microbial Drug Res. 2010;16:12. https://doi.org/10.1089/mdr.2009.0127.

79. Akoachere JTK, Omam L, Massall NT. Assessment of the relationship between bacteriological quality of dug-wells, hygiene behaviour and well characteristics in two cholera endemic localities in Douala, Cameroon. BMC Pub Health. 2013;13:692.

80. Akoachere JTK, Masalla NT, Njom AH. Multi-drug resistant toxigenic Vibrio cholerae $\mathrm{O} 1$ is persistent in water sources in new bell-Douala, Cameroon. BMC Infect Dis. 2013;13:366.

81. Akoachere JTK, Nana G, Dilonga MH, Nkuo-Akenji KT. Public health implications of contamination of franc CFA (XAF) circulating in Buea (Cameroon) with drug resistant pathogens. BMC Res Notes. 2014;7:16.

82. Akoachere JTK, Mbuntcha KC. Water sources as reservoirs of Vibrio cholerae 01 and non-O1 strains in Bepanda, Douala, Cameroon: relationship between isolation and physico-chemical factors. BMC Infect Dis. 2014;14:421.

83. Okalla Ebongue C, Nguatcheussi MC, Nda Mefo'o J, Bollanga J, Adiogo D, Luma NH. Microbial ecology and antibiotic susceptibility profile of germs isolated from hospital surfaces and medical devices in a reference Hospital in Douala, Cameroon. Adv Microbiol. 2018;8:125-37.

84. O'Neill J. Tackling drug-resistant infections globally: final report and recommendations. 2016. https://amr-review.org/sites/default/files/160525_ Final\%20paper_with\%20cover.pdf.

85. Mwanyika GO, Subbiah M, Buza J, Rugumisa TB, Call R. A systematic review of antibiotic-resistant Escherichia coli and Salmonella data obtained from Tanzanian healthcare settings (2004-2014). Afr J Microbiol Res. 2017;11(2): 45-54. https://doi.org/10.5897/AJMR2016.8282.

86. Chem E, Anong D, Akoachere JTK. Prescribing patterns and associated factors of antibiotic prescription in primary health care facilities of Kumbo east and Kumbo west health districts, North West Cameroon. PLoS One. 2018;13(3):e0193353. https://doi.org/10.1371/journal.pone.0193353.

87. Ngu C, Feteh F, Kika T, Ketchemen E, Ayeah C, Chifor T, Njim T, Fankem A, Fai YK. Prevalence and determinants of antibiotic self-medication among adult patients with respiratory tract infections in the Mboppi Baptist hospital, Douala, Cameroon: A Cross-Sectional Study. Diseases. 2018;6:49. https://doi.org/10.3390/diseases6020049.

88. Founou LL, Amoako GD, Founou RC, Essack YS. Antibiotic resistance in food animals in Africa: a systematic review and meta-analysis. Microbial Drug Res. 2018. https://doi.org/10.1089/mdr.2017.0383.

89. FAO. Antimicrobial Resistance in the Environment: Summary Report of an FAO Meeting of Experts FAO Antimicrobial Resistance Working Group, ParisFrance; 2018. p. 3.

90. FAO/OMS/OIE. Réunion mixte d'experts FAO/OMS/OIE sur les agents antimicrobiens d'importance critique. Rapport de la réunion d'experts FAO/ OMS/OIE Siège de la FAO, Rome 26-30 Novembre 2007. 2011; 84p-E-ISBN 978-992-975-206009-206003 (PDF).

91. Njingou NBZ. Pharmacovigilance vétérinaire au Cameroun : état des lieux et évaluation des Connaissances des acteurs de la filière du médicament vétérinaire. Ngaoundéré: Thèse Med. vet., ESMV; 2014. p. 55-8.

92. OHCEA. Evaluation du cadre juridique et institutionnel de la lute contre la résistance aux antimicrobiens au Cameroun : Etude exploratoire. Yaoundé; 2017b. p. 35.

93. Têko-agbo A, Messomo ndjana F, Walbadet L, Akoda K, Niang M, Abiola F. Qualité des médicaments vétérinaires en circulation au Cameroun et au Sénégal. Dakar Méd. 2009:54:226-34.

94. Afnabi R, Nameni R, Kamdem S, Ngang J, Alambedji R. Microbial load of beef sold in the traditional slaughterhouse and butcher shops in northern Cameroon. Int J Vet Sci. 2015;4(4):183-9. 
95. Wouafo M, Nzouankeu A, Kinfack AJ, Fonkoua M, Ejenguele G, Njine T, Ngandjio A. Prevalence and Antimicrobial Resistance of Salmonella Serotypes in Chickens from Retail Markets in Yaounde, Cameroon. Microbial Drug Res. 2010;16(12). https://doi.org/10.1089/mdr.2009.0127.

96. Zinstag J, Schelling E, Waltner-Toews D, Tanner M. From "one medicine" to "one health" and systemic approaches to health and well-being. Prev Vet Med. 2011;101:148-56.

97. Dickin SK, Schuster-Wallace CJ, Qadir M, Pizzacalla KA. Review of health risks and pathways for exposure to wastewater use in agriculture. Environ Health Persp. 2016;124:900-129.

98. MINSANTE. Plan d'action national de lutte contre la résistance aux antimicrobiens 2018-2020. Ministère de la santé publique. 2018:116.

\section{Publisher's Note}

Springer Nature remains neutral with regard to jurisdictional claims in published maps and institutional affiliations.

- fast, convenient online submission

- thorough peer review by experienced researchers in your field

- rapid publication on acceptance

- support for research data, including large and complex data types

- gold Open Access which fosters wider collaboration and increased citations

- maximum visibility for your research: over $100 \mathrm{M}$ website views per year

At $\mathrm{BMC}$, research is always in progress. 